\title{
Cancer non-stem cells as a potent regulator of tumor microenvironment: a lesson from chronic myeloid leukemia
}

\author{
Naofumi Mukaida* (D), Yamato Tanabe and Tomohisa Baba
}

\begin{abstract}
A limited subset of human leukemia cells has a self-renewal capacity and can propagate leukemia upon their transplantation into animals, and therefore, are named as leukemia stem cells, in the early 1990's. Subsequently, cell subpopulations with similar characteristics were detected in various kinds of solid cancers and were denoted as cancer stem cells. Cancer stem cells are presently presumed to be crucially involved in malignant progression of solid cancer: chemoresitance, radioresistance, immune evasion, and metastasis. On the contrary, less attention has been paid to cancer non-stem cell population, which comprise most cancer cells in cancer tissues, due to the lack of suitable markers to discriminate cancer non-stem cells from cancer stem cells. Chronic myeloid leukemia stem cells generate a larger number of morphologically distinct non-stem cells. Moreover, accumulating evidence indicates that poor prognosis is associated with the increases in these non-stem cells including basophils and megakaryocytes. We will discuss the potential roles of cancer non-stem cells in fostering tumor microenvironment, by illustrating the roles of chronic myeloid leukemia non-stem cells including basophils and megakaryocytes in the pathogenesis of chronic myeloid leukemia, a typical malignant disorder arising from leukemic stem cells.
\end{abstract}

Keywords: Basophil, Cancer stem cell, Leukemia stem cell, Megakaryocyte, Tissue-resident stem cell

\section{Introduction}

Pluripotent stem cells in embryo can self-renew and can generate all mature cell types in the body as their potency to self-renew progressively decreases [1]. Adult organs possess populations of tissue-resident stem cells, which are capable of self-renewal to differentiate into all types of cells in the corresponding tissue [2]. Tissueresident stem cells can generate new stem cells through symmetric divisions (producing two similar stem cells) or asymmetric divisions (producing a stem cell and a non-stem cell) (Fig. 1) [3]. The resultant tissue-resident cells can be sustained by interacting with their microenvironment, niche, through activation of various

\footnotetext{
* Correspondence: mukaida@staff.kanazawa-u.ac.jp; http://orcid.org/00000002-4193-1851:

Division of Molecular Bioregulation, Cancer Research Institute, Kanazawa University, Kakuma-machi, Kanazawa 920-1192, Japan
}

signaling pathways, particularly Wnt/ $\beta$-catenin, Hedghog, and Notch pathways [2]. Simultaneously, nonstem cells lose self-renewal capacity and differentiate through a progenitor stage with a restricted differentiation capacity, to mature cell types, which are specific to their tissue of origin [2, 3]. Thus, tissue-resident stem cells are crucial for tissue homeostasis maintenance under both physiological and pathological conditions.

A seminal study reported the presence of a minor fraction of leukemia cells which can in vitro continue to proliferate similarly as hematopoietic stem cells (HSCs) can [4]. In 1990's, evidence is accumulating to indicate that these cells have a self-renewal capacity and can propagate leukemia upon their serial transplantation into animals $[5,6]$. Based on these properties, they are named as leukemia-initiating cells or leukemia stem cells (LSCs) [7]. Subsequently, cell subpopulations with similar characteristics were detected in various kinds of solid cancers 


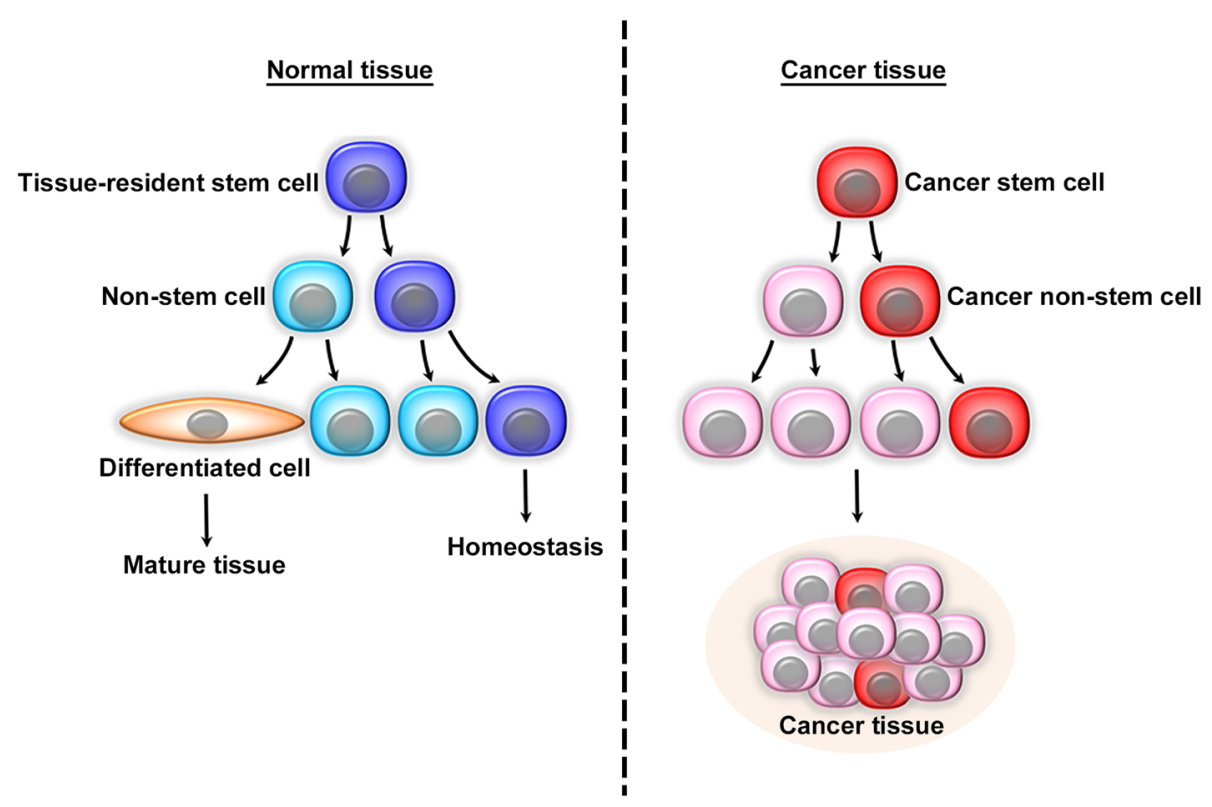

Fig. 1 Hierarchy of stem and non-stem cells in normal and cancer tissues. Normal tissue-resident stem cells generate new stem cells through symmetric divisions (producing two similar stem cells) or asymmetric divisions (producing one stem and one non-stem cells). Stem cells selfrenew to maintain homeostasis while non-stem cells lose self-renewal capacity and differentiate into mature cell types to exert normal tissue functions. Like normal tissue-resident tissue stem cells, CSCs generate a small number of CSCs with self-renewal capability and cancer non-stem cells, which predominate cancer tissues

including breast [8], brain [9, 10], colorectal [11], hepatocellular [12], and pancreatic cancers [13], and melanomas [14], and have been termed as cancer-initiating cells or cancer stem cells (CSCs). Like normal tissue-resident stem cells, LSCs and CSCs have a self-renewal ability to generate new stem cells through symmetric or asymmetric divisions $[15,16]$. Self-renewal capacity of CSCs is maintained by the activation of several signaling pathways used by tissue-resident stem cells, such as Wnt/ $\beta$-catenin $[17,18]$, Hedgehog [19], or Notch pathway [20], in a cell contextdependent manner. CSCs are presumed to be crucially involved in various carcinogenesis steps, particularly malignant progression $[15,16]$. In addition to CSCs, asymmetric divisions simultaneously generate cancer nonstem cell populations which compose most of cancer cells present in cancer tissues (Fig. 1), but the roles of cancer non-stem cells in carcinogenesis are often overlooked.

In this review, we will briefly summarize biological aspects of CSCs and will discuss the potential roles of cancer non-stem cells in tumor microenvironment formation, by delineating the roles of non-stem cells in the pathogenesis of chronic myeloid leukemia (CML), a typical malignant disorder arising from LSCs.

\section{Properties of Cancer stem cells (CSCs) Cellular origin of CSCs}

CSCs show very similar phenotypes to tissue-resident normal stem cells, and indeed, in several types of cancers, tissue-resident stem cells are the origin of CSCs (Fig. 2). For example, crypt stem cells are the origin of intestinal cancer [21] while skin basal cancer can arise from hair follicle stem cells [22]. This may arise from the conversion of normal stem cells to CSCs by random mutation accumulation during DNA replication [23]. Moreover, oncogenic $B C R-A B L$ can transform hematopoietic stem cells into LSCs, and eventually can induce CML. On the contrary, other leukemogenic fusion genes, such as MLL-ENL [24] or the MOZ-TIF gene [25] can convert more committed hematopoietic progenitor cells (HPCs) into LSCs of acute myeloid leukemia (AML). Similarly, PIK3CA ${ }^{\text {H1047R }}$, the most frequent mutation observed in human breast cancer, can dedifferentiate lineage-committed cells of adult mouse mammary glands into multipotent CSC-like cells [26]. Thus, CSCs are derived from differentiated cells as well as tissue-resident multipotent stem cells (Fig. 2).

Accumulating evidence indicates that cancer non-stem cells can acquire CSC-like phenotypes under various conditions (Fig. 2). Genomic instability induces cancer non-stem cells to acquire CSC-like phenotypes, when the instability is enhanced by various causes including DNA damages induced by ultraviolet and mitomycin C, overexpression of a key regulator of cell cycle, Mad2, inhibition of an important kinase in mitosis such as Aurora B, or a key E3 ligase in cell cycle such as Cdh1 [27]. These events account for genomic instability-induced 


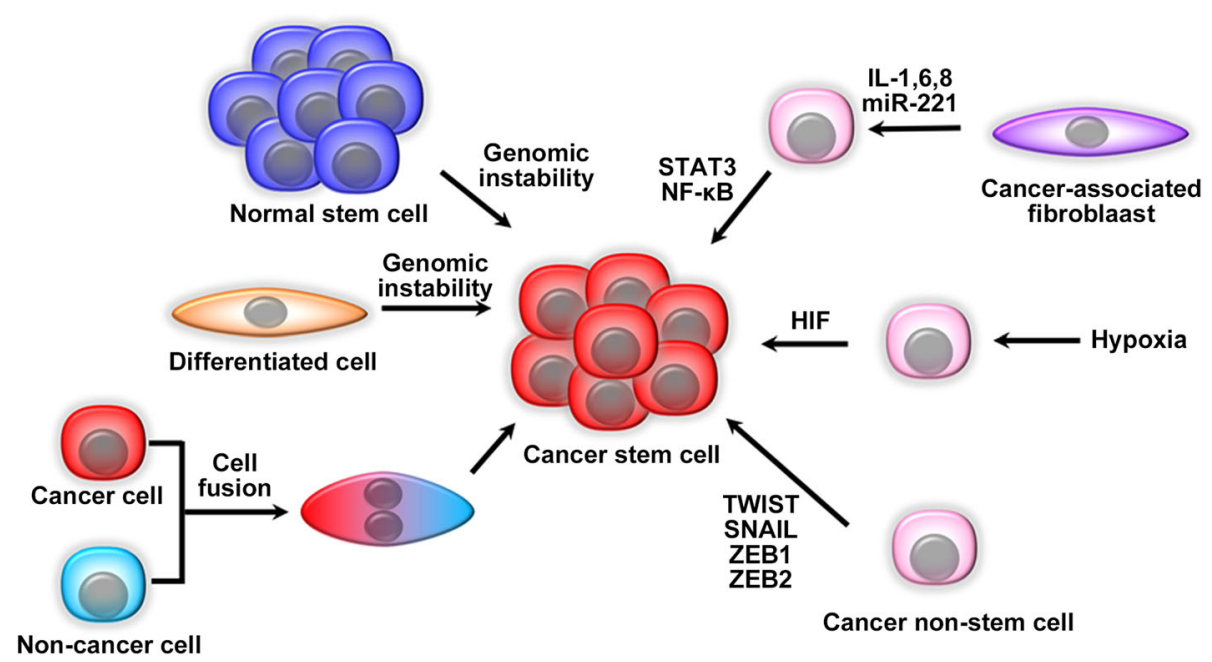

Fig. 2 The origin of CSCs. Genetic mutations generate CSCs from tissue resident stem cells or differentiated cells. CSCs can be generated also by cell fusion between normal and cancer cells. Hypoxia induces cancer non-stem cells to display CSC phenotypes by activating hypoxia inducible factor (HIF) or signal transducer and activator of transcription (STAT)3 pathway. Moreover, the interaction between cancer and stromal cells produces various cytokines to activate STAT3/nuclear factor (NF)-KB pathways in both cancer and stromal cells, thereby driving CSC generation from non-CSC populations. Furthermore, CSCS are generated from non-CSC population by the action of a number of EMT-inducing transcription factors such as TWIST, SNAIL, ZEB1, and ZEB2

generation of CSCs from cancer non-stem cells, particularly at tumor recurrence after anti-cancer treatment. Injury to a tissue can enhance spontaneous fusion of tissue resident stem cells with non-stem cells, which can generate new hybrid pluripotent cells [28]. It was proposed that similar cell-cell fusion events can occur among cancer cells or between cancer cells and normal cells, and can eventually create CSCs [29]. This assumption is substantiated by the observations that human breast cancer cells acquired CSC-like phenotypes through the fusion with normal breast epithelial cells [30] or adipose tissuederived stem cells [31]. Normal resident cells present in tumor microenvironment can maintain CSC phenotypes by secreting various mediators. Endothelial cells can sustain CSCs by secreting interleukin (IL)-6 [32, 33] or basic fibroblast growth factor [34], while fibroblasts can maintain CSC phenotypes by secreting soluble mediators such as a chemokine, CCL2 [35, 36].

The activation of transcription factors can trigger CSC generation from non-CSC population (Fig. 2). Hypoxia induces cancer non-stem cells to exhibit CSC-like phenotypes by activating hypoxia-inducible factor [37] or signal transducer and activator of transcription (STAT)3 pathway [38]. IL-6-STAT3 pathway activation induced cancer-associated fibroblasts (CAFs) to generate microvesicles containing miR-221, which was horizontally transferred to breast cancer non-stem cells, thereby promoting their acquisition of CSC-like phenotypes, particularly in combination with hormone therapy [39]. Additionally, cancer and stromal cells produce various inflammatory cytokines, such as IL-1, IL-6, and IL-8, which in turn activate STAT3/NF- $\kappa B$ pathways in both cancer and stromal cells [40]. Activation of these pathways further enhances cytokine production and eventually forms a positive feedback loops that in turn drive CSC generation from cancer non-stem cells and their self-renewal. Additionally, as CSC generation from cancer non-stem cells can be promoted by a number of transcription factors including TWIST, SNAIL, ZEB1, and ZEB2, the transcription factors that regulate epithelialmesenchymal transition (EMT), CSC generation is accompanied by EMT [41, 42], which can provide epitheliumderived cancer cells with mesenchymal phenotypes including a motile capacity to exit from the primary sites [43]. Thus, CSCs are presumed to be prone to metastasize due to their mesenchymal phenotypes [43].

\section{Phenotypes of CSCs}

CSCs are defined functionally as a cancer cell with a capacity to develop tumor upon its serial transplantation into an animal or to form in vitro spheres upon serial passages $[15,16]$. However, both assays are timeconsuming and lack reproducibility as exemplified by differences in tumorigenic capacity according to the types of transplanted animals [14]. Thus, a vast number of studies have been conducted to identify surface markers, which are expressed selectively by CSCs (Table 1) [44]. CD44 is a transmembrane glycoprotein, which arises from a single gene which in humans contains 19 exons, but its alternative splicing generates variant CD44 isoforms $(\mathrm{CD} 44 \mathrm{v})$ as well as the standard form of CD44 (CD44s) [45]. CD44 is expressed by CSCs in various 
Table 1 Representative surface markers to identify CSCs in various types of cancers

\begin{tabular}{llll}
\hline Surface marker & Cancer type & Reference \\
\hline CD15 & glioblastoma, medulloblastoma & {$[44]$} \\
CD24 & breast, liver, colon, gastric cancer & \\
CD33 & acute myeloid leukemia & {$[44]$} \\
CD44 & breast, ovary, prostate and pancreas cancer, head and neck squamous cell carcinoma & {$[44]$} \\
CD123 & acute myeloid leukemia & {$[45]$} \\
CD133 & breast, ovary, prostate, colon, liver, lung, and renal cancer, glioblastoma, medulloblastoma & {$[44]$} \\
CD166 & lung, colon cancer & {$[46]$} \\
\hline
\end{tabular}

types of cancers including breast, ovary, prostate, and pancreas cancer, head and neck squamous cell cancers, and can sustain stemness by interacting with hyaluronan present in CSC niche [47]. Another notable surface marker of CSCs is CD133 [46], which is a five transmembrane glycoprotein consisting of two large extracellular loops and two small cysteine-rich intracellular loops [48]. CD133 is expressed also by CSCs in various types of cancers including breast, ovary, prostate, colon, liver, lung, and renal cancers, glioblastoma, and medulloblastoma, but it still remains elusive on the roles of CD133 in CSC maintenance.

Aldehyde dehydrogenase (ALDH)1, a member of ALDH family, is a detoxifying enzyme responsible for intracellular aldehyde oxidation [49] and can induce the differentiation of stem cells by oxidizing retinol to retinoic acid [50]. ALDH1 is abundantly expressed in CSCs of breast [51], ovarian [52] and colorectal cancers [53]. ALDH1-expressing cells can be identified by using flow cytometry-based Aldefluor assay, which relies on a capacity of ALDH1 to convert a non-fluorescent molecule to a fluorescent product [54]. An additional flow cytometrical method is used to detect CSCs, based on their augmented expression of $\mathrm{ABC}$ transporters including ATP-binding cassette subfamily-B member 1 (ABCB1) and ATP-binding cassette subfamily-G member 2 (ABCG2) [55]. With these transporters, CSCs can eject out a fluorescent dye, Hoechst 33342, with a high efflux efficiency and appear as a negatively-stained population or side population (SP) on a flow cytometry [56].

Until present, no single molecules, however, have been identified as a specific marker for CSCs. Moreover, even with the combined use of several markers, the proportions of CSCs among total cancer cells are frequently estimated to be high in solid cancers, reaching higher than $10 \%$. Considering that normal tissue-resident stem cells comprise less than $1 \%$ of total cells, it is highly likely that hitherto identified CSCs contain non-CSC population in solid cancers. Thus, identification of specific markers is required to discriminate CSC from non-CSC populations and to elucidate the functions of CSCs and cancer non-stem cells in more detail.

\section{Pathological roles of CSCs}

Evidence is accumulating to indicate the crucial involvement of CSCs in various aspects of malignant progression of cancer cells, including resistance to therapy [57], immune evasion [58], and metastasis [59]. Several mechanisms are presumed to account for CSC-mediated resistance to anti-cancer therapies (Fig. 3). In order to maintain tissue homeostasis, adult tissue-resident stem cells are in a state of cellular dormancy, where cells are recruited into $G_{0}$ phase but remain capable of cell division in response to mitotic stimuli [60]. CSCs are also in a cellular dormant state and as a consequence, are resistance to chemotherapy and irradiation, which are mainly effective against proliferating cells [61]. However, as non-CSC population can also be moved into a dormant state [62], non-CSC population can also contribute to resistance to anti-cancer therapy. Additionally, most anti-cancer treatments can induce apoptosis in cancer cells [63] but CSCs in prostate and breast cancer exhibit enhanced expression of a potent anti-apoptotic molecule, B-cell lymphoma 2 (Bcl-2) [64, 65], thereby counteracting drug-induced apoptosis. Moreover, CSCs express higher levels of $\mathrm{ABC}$ transporters including ABCB1 and ABCG2, than non-CSC population [55]. These transporters can efficiently expel a wide variety of chemotherapeutic drugs including alkylating agents, antimetabolites, topoisomerase inhibitors, taxanes, and vinca alkaloids [66] and eventually endow CSCs with resistance to these drugs. Furthermore, normal tissueresident stem cells and CSCs express higher levels of reactive oxygen species (ROS) scavengers, such as glutathione biogenesis synthesis genes, thereby preventing ROSinduced DNA damages upon irradiation [67]. Glioma CSCs exhibit radioresistance by augmenting DNA checkpoint activation as evidenced by increased phosphorylation of the ataxia-telangiectasia-mutated (ATM), checkpoint 1 (Chk1), and Chk2 [68].

CSCs are equipped with an ability to suppress the recognition by innate and adaptive immunity and to reshape tumor microenvironment into an immunosuppressive one (Fig. 3). CSCs recruit macrophages and induce their polarization towards M2 


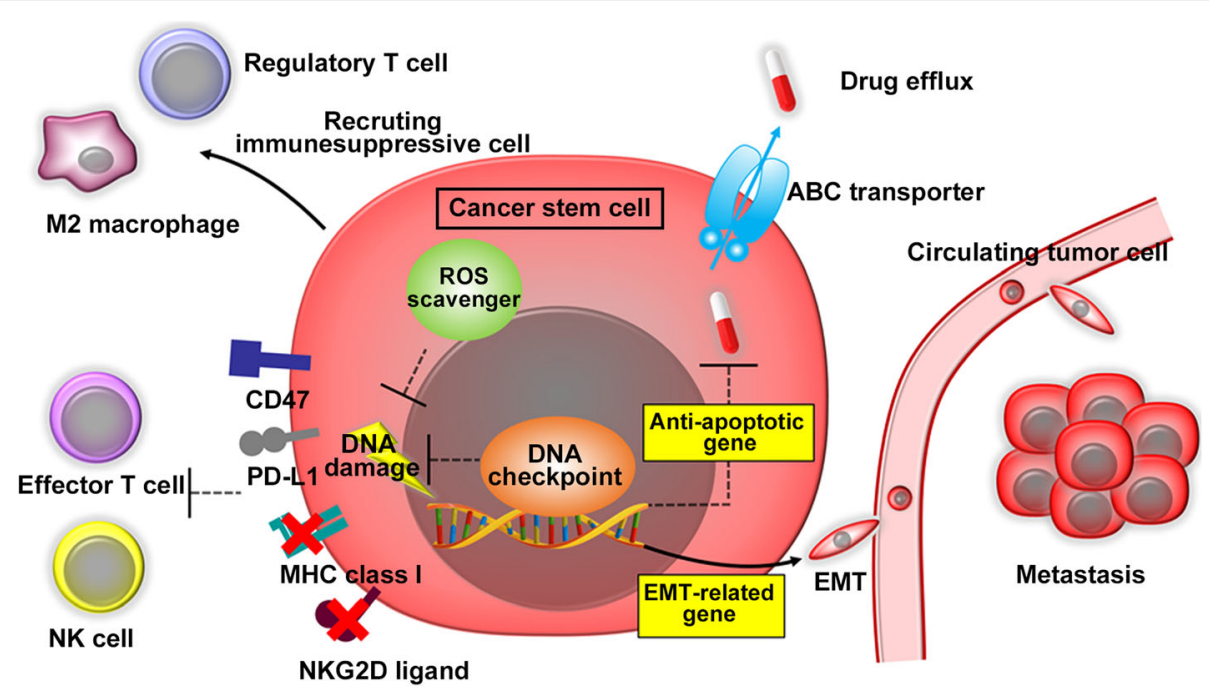

Fig. 3 Presumed biological properties of CSCs. CSCs are in a dormant state and therefore, are resistance to chemotherapy and irradiation, which are mainly effective against proliferating cells. Moreover, CSCs exhibit enhanced expression of ABC transporters and anti-apoptotic molecules, efficiently expel chemotherapeutic drugs and to counteract drug-induced apoptosis, respectively. Furthermore, CSCs display higher levels of reactive oxygen species (ROS) scavengers and augmented DNA checkpoint activation, to counteract ROS-induced adverse effects and to prevent DNA damages, respectively. CSCs dampen tumor immunity by inhibiting effector T cell and inducing immunosuppressive M2-macrophages and regulatory T cells (Tregs). Moreover, CSCs exhibit enhanced expression of immune checkpoint molecules to hamper T cell-mediated tumor immunity. CSCs further express reduced expression of HLA class I antigen and KKG2D ligand to escape cytotoxicity mediated by effector T cells and natural killer (NK) cells, respectively. Furthermore, CSCs display EMT phenotypes, which are indispensable for metastasis processes

macrophage with a capacity to inhibit immune response [69]. Melanoma and glioma CSCs can inhibit effector T cell activation and simultaneously can induce regulatory $\mathrm{T}$ cells (Treg), thereby counteracting specific tumor immunity [70, 71]. Moreover, compared with non-CSC population, CSCs in breast and lung cancers express higher levels of immune checkpoint molecules including PD-L1 [72] and CD47 [73], respectively. PD-L1 and CD47 can inhibit the activities of activated $\mathrm{T}$ cells and macrophages, respectively, thereby hampering tumor immunity. Furthermore, lung cancer CSCs and AML LSCs exhibit reduced expression of HLA class I antigen [74] and NKG2D ligand [75], respectively. Decreased HLA class I antigen and NKG2D expression can constrain cytotoxicity mediated by effector $\mathrm{T}$ cells and natural killer cells, respectively.

CSCs are presumed to contribute also to metastasis process. EMT provides cancer cells with mobile mesenchymal cell-like phenotypes, which can facilitate their exit from the primary sites and therefore, is an essential step for metastasis [43]. As EMT can induce cancer cells to express CSC phenotypes [41, 42], CSCs exhibit EMT phenotypes, which are presumed to have crucial roles in metastasis [76]. Moreover, circulating tumor cells have an ability to metastasize to distant organs and exhibit specific changes in DNA methylation that are shared by CSCs [77]. However, more detailed studies are necessary to elucidate the roles of CSCs in metastasis.

CSCs have presently been an intensive focus of cancer research due to their crucial involvement in malignant progression processes such as therapy resistance, immune evasion, and metastasis, whereas less attention is paid to cancer non-stem cells, which compose most cancer cells in cancer tissues. The study on cancer nonstem cells meets with difficulties due to the shared functional and phenotypic characteristics between CSCs and cancer non-stem cells in solid cancer. In CML, however, non-stem cells, major components of leukemia cells, are phenotypically distinct from stem cells [78]. Thus, CML can be a good subject to study the roles of non-stem cells in carcinogenesis. In the following sections, we will discuss the potential roles of non-stem cells in CML pathogenesis, in order to facilitate the understanding of the roles of cancer non-stem cells in solid tumor progression.

\section{Chronic myeloid leukemia (CML)}

\section{Leukemia stem cells (LSCs) in CML}

CML harbors a characteristic abnormal chromosome, the Philadelphia chromosome $(\mathrm{Ph})$, which arises from a reciprocal translocation between the long arm of chromosome 9 (ch9) and 22 (ch22) [78]. This reciprocal translocation replaces the upstream control element of the $A B L-1$ gene, the human analogue of the $v-A B L$ oncogene, with the $B C R$ gene and generates $B C R-A B L$ fusion gene, which encodes a constitutively activating tyrosine kinase with a capacity to phosphorylate various substrates including molecules involved in cell proliferation [79]. As a consequence, $B C R-A B L$-expressing 
hematopoietic cells can proliferate as LSCs to induce pathological changes observed in CML [80, 81] (Fig. 4). Moreover, the transduction of $B C R-A B L$ gene conferred the capacities to self-renew in vitro and to cause leukemogenesis on murine HSCs but not HPCs [25] in contrast to acute myeloid leukemia models, where leukemia can develop upon the transduction into HPCs of oncogenic fusion genes such as the MLL-ENL [24] or the MOZ-TIF gene [25]. Thus, it is probable that CML LSCs are derived from BCR-ABL-transformed HSCs. However, a single $B C R-A B L$ copy expressed from endogenous $B C R$ locus, enhanced bone marrow grafting capacity without inducing any neoplasm [82]. Thus, $\mathrm{BCR}-\mathrm{ABL}$ is prerequisite but not sufficient for CML LSC generation, which might additionally require $B C R-A B L$ copy number amplification, secondary mutations and/or genomic instability [78].

In CML, LSCs are presumed to reside within lineage marker (Lin) ${ }^{-} \mathrm{CD} 34^{+} \mathrm{CD} 38^{-}$fraction of leukemia cells [83, 84], but this phenotype is shared by normal HSCs [85]. Subsequent studies identified IL-2 receptor- $\alpha$ (CD25) [86], dipeptidyl peptidase 4 (DPP4, CD26) [85], Siglec-3 (CD33) [85], scavenger receptor-B2 (SR-B2, CD36) [85, 87], and IL-1 receptor accessory protein (IL-1RAP) [85, 88] as surface markers expressed predominantly by CML LSCs (Table 2). Several mechanisms are presumed to be involved in CML LSC maintenance and survival (Fig. 5). Phosphoinositide 3-kinase (PI3K)/Akt/FOXO axis [89], Wnt signaling $[90,91]$, and Janus kinase (JAK)2/STAT5 signaling [92], are directly activated by kinase activity of BCR-ABL and sustain LSC survival. Moreover, frequent failure of BCR-ABL kinase inhibitors to eradicate completely CML LSCs suggests the involvement of BCRABL kinase-independent intrinsic pathways in LSC maintenance. Indeed, activation of Hedgehog signaling [93] and ALOX5 [94] can sustain LSC survival independently of BCR-ABL kinase activity. LSC survival further requires their localization to bone marrow niche with the help of several LSC-expressing adhesion molecules such as cadherins [95], CD44 [96], and galectin-3 [97]. Furthermore, bone marrow resident cells maintain CML LSCs by secreting various soluble factors such as Jagged 1 (a NOTCH ligand) [98], transforming growth factor (TGF)- $\beta 1$ [99], bone morphogenic proteins (BMPs) [100], a chemokine, CXCL12 [101], IL-1 [102], and exosomes containing miR-126 [103].

\section{Clinical aspects of CML}

CML has three distinct clinical phases: chronic phase (CP), accelerated phase (AP), and blast phase (BP) [104]. At diagnosis, most CML patients are in $\mathrm{CP}$, which is characterized by increases in neutrophil, eosinophil and basophil numbers in peripheral blood and bone marrow, with the predominance of mature leukocytes over blasts (usually less than $5 \%$ ). As the origin of CML LSCs is HSCs, a minor population among hematopoietic cells [25], BCR-ABL generates only a limited number of LSCs. LSCs appear in bone marrow in a small number and proliferate clonally in competition with a large number of normal hematopoietic cells. Thereafter, LSCs occupy bone marrow and eventually migrate into other tissues including peripheral blood and spleen (Fig. 4). As CML LSCs still share a differentiation ability with normal HSCs, CP-CML LSCs simultaneously differentiate into various morphologically mature but molecularly malignant BCR-ABL-expressing leukocytes. Thus, the leukocytes in $\mathrm{CP}$ are heterogeneous, consisting of a small number of LSCs with the majority of leukemia non-stem

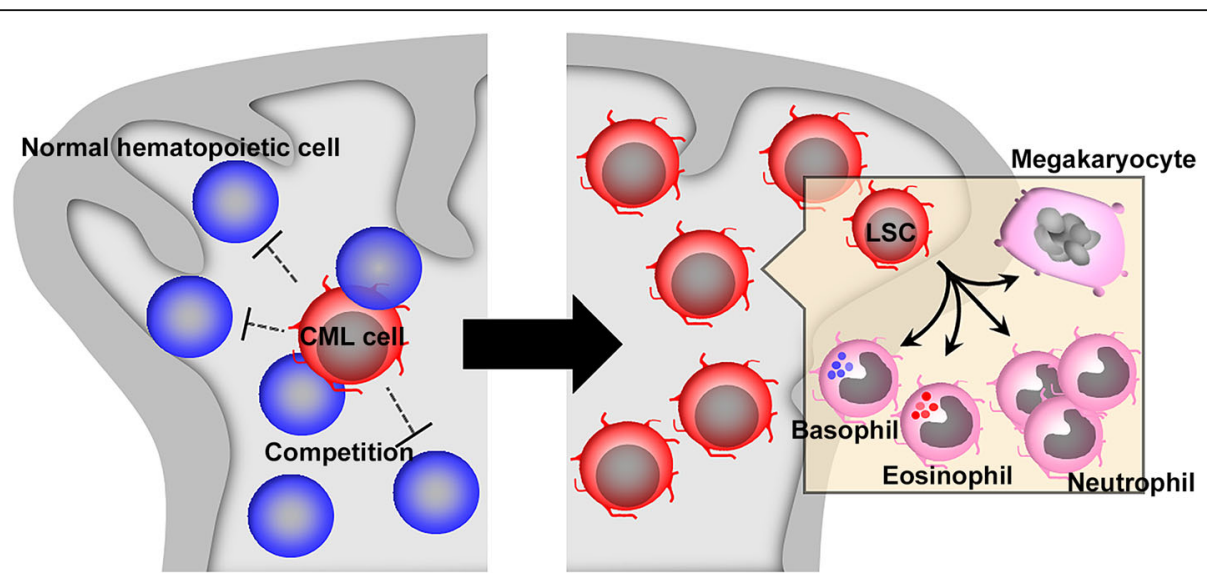

Fig. 4 CML progression. BCR-ABL gene transforms HSCS into LSCS, which gradually and clonally proliferate in competition with a large number of normal hematopoietic cells to eventually occupy bone marrow and migrate into other tissues including peripheral blood and spleen. CML LSCS simultaneously differentiate into more mature leukemia non-stem cells and as a consequence, CML cells consist of a small number of LSCs with the majority of leukemia non-stem cells including neutrophils, eosinophils, basophils and megakaryocytes. Moreover, these differentiated cells morphologically exhibit distinct features from LSCs but similar characteristics with normal counterparts 
Table 2 Expression pattern of surface markers on normal and $\mathrm{CML} C D 34^{+} \mathrm{CD} 38^{-}$and $\mathrm{CD} 34^{+} \mathrm{CD} 38^{+}$cell populations

\begin{tabular}{|c|c|c|c|c|c|}
\hline Marker & 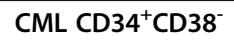 & Normal CD34 ${ }^{+} \mathrm{CD}_{38}^{-}$ & 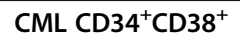 & Normal CD $34^{+} \mathrm{CD}_{38^{+}}$ & \\
\hline $\begin{array}{l}\text { IL-2 receptor } \boldsymbol{a} \\
\text { (CD25) }\end{array}$ & ++ & - & $+/-$ & $+/-$ & [86] \\
\hline $\begin{array}{l}\text { Dipeptidyl peptidase } 4 \\
\text { (DPP4, CD26) }\end{array}$ & ++ & - & $+/-$ & - & [85] \\
\hline $\begin{array}{l}\text { Siglec-3 } \\
\text { (CD33) }\end{array}$ & ++ & - & + & ++ & [85] \\
\hline $\begin{array}{l}\text { scavenger receptor-B2 } \\
\text { (SR-B2, CD36) }\end{array}$ & ++ & $+/-$ & ++ & ++ & {$[85,87]$} \\
\hline IL-1 receptor accessory protein (IL-1RAP) & + & - & + & + & {$[85,88]$} \\
\hline
\end{tabular}

cells (Fig. 4). Nonetheless, tyrosine kinase inhibitors (TKIs) targeting BCR-ABL can efficiently eradicate most BCR-ABL-expressing CP-CML cells and as a consequence, have drastically improved the prognosis of $\mathrm{CP}$ CML patients since their clinical introduction two decades ago [104].

$\mathrm{BP}$ is defined as the state of an increased proportion of blasts (usually more than $20 \%$ ) in blood or bone marrow and is also called as blast crisis, while AP is an intermediate phase between $\mathrm{CP}$ and $\mathrm{BP}$, with resistance to TKIs and less blasts (less than $20 \%$ ) in blood or bone marrow [105]. Thus, BP is generally a late feature of progression but is also observed in a small proportion of newly diagnosed CML patients [106]. Evidence is accumulating to indicate that LSCs in CP may evolve into those in BP through several molecular changes. BCR/ ABL affects the efficiency and fidelity of major DNA double strand breaks (DSBs) repair mechanisms by stimulating WRN (mutated in Werner syndrome), thereby facilitating genomic instability [107]. Genomic instability predisposes to additional gene mutations, which are observed in BP-CML cells, such as p16

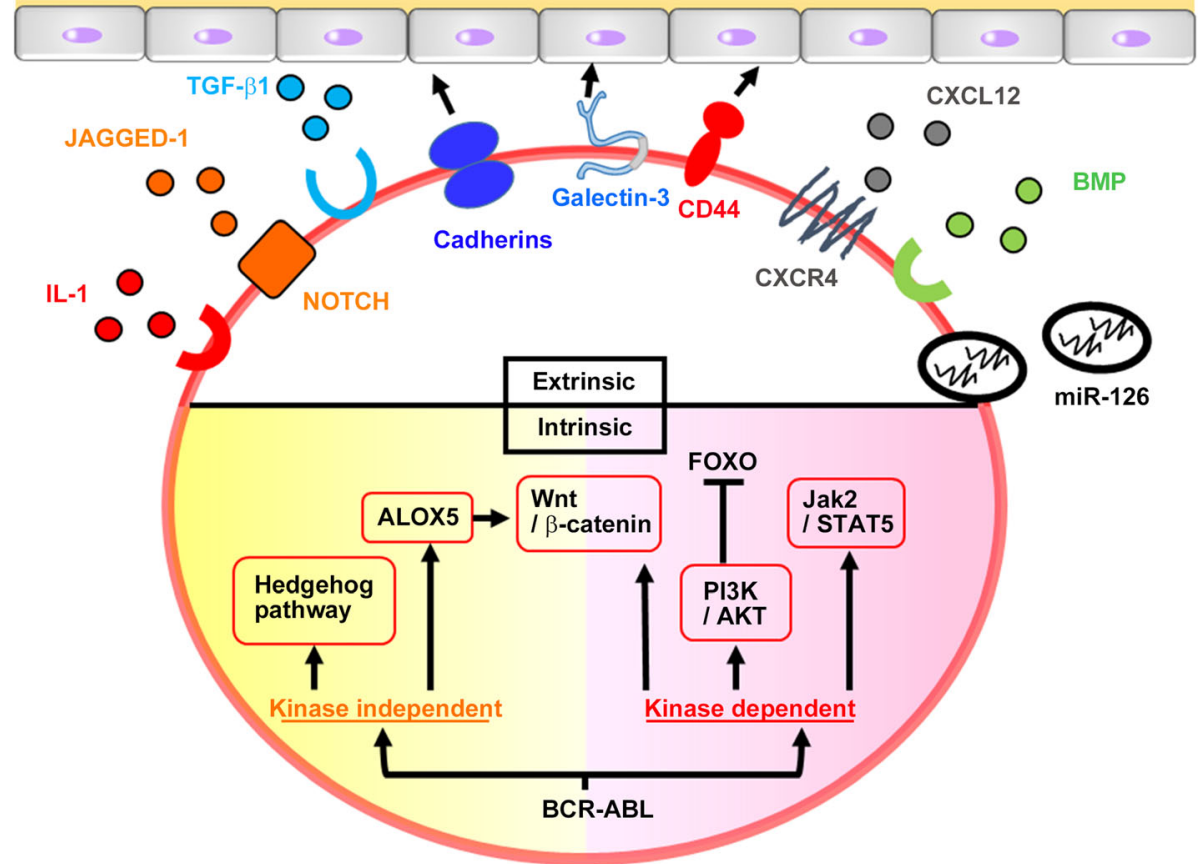

Fig. 5 Presumed mechanisms involved in CML LSC maintenance. Phosphoinositide 3-kinase (PI3K)/Akt/FOXO axis [89], Wnt signaling [90, 91], and janus kinase (JAK)2/ signal transducer and activator of transcription (STAT)5 signaling [92], are directly activated by kinase activity of BCR-ABL and sustain LSC survival. Moreover, activation of Hedgehog signaling [93] and ALOX5 [94] can maintain LSC survival independently of BCR-ABL kinase activity. LSC survival further requires their localization to bone marrow niche with the help of several LSC-expressing adhesion molecules such as cadherins [95], CD44 [96], and galectin-3 [97]. Furthermore, bone marrow resident cells secrete various mediators including Jagged 1 (a NOTCH ligand) [98], transforming growth factor (TGF)- $\beta 1$ [99], bone morphogenic proteins (BMPs) [100], a chemokine, CXCL12 [101], interleukin (IL)-1 [102], and exosomes containing miR-126 [103] to sustain the stemness of CML LSCS 
deletion [108], p53 loss of function [109], loss of retinoblastoma gene product [110], increased Evi-1 expression [111], or mutations in RUNX-1, ASXL1, and isocitrate dehydrogenases [112]. Moreover, aberrant histone deacetylase activities induce epigenetic dysregulation, thereby conferring more aggressive phenotypes on cells in BP [113]. Musashi2, an oncogenic RNA binding protein, is aberrantly expressed in BP leukemia cells and is physically associated with the transcript of BCAT1, a cytosolic aminotransferase for branched-chain amino acids to enhance its expression and to eventually promote cell proliferation [114]. Intrinsic refractoriness of AP-blast cells to TKIs commonly necessitates additional chemotherapeutic agents, which are mostly ineffective [106].

TKI treatment can keep CP-CML patients under favorable long-term disease control with about $90 \%$ overall survival, $90 \%$ complete cytogenetic response, and 90 $\%$ major molecular response which was defined as a reduction of at least $3 \mathrm{log}$ in the BCR-ABL1 value from the standardized baseline level on the International Scale, at 10 years after the treatment initiation [115]. This incited the attempt to discontinue TKI treatment in CP-CML patients in 2-year long molecular remission defined as $B C R-A B L / A B L$ levels lower than a detection threshold corresponded to a 5-log reduction [116]. This first study demonstrated that approximately $40 \%$ CPCML patients did not relapse until 1 year after the discontinuation of a TKI, imatinib, and that all relapsing patients responded well to the reintroduction of imatinib. These observations were validated by a subsequent meta-analysis on CML patients who underwent imatinib termination [117]. Moreover, a large-scale multi-center trial demonstrated that molecular relapse-free survival was $50 \%$ at 24 months after the treatment discontinuation, in the patients who were treated with imatinib or second-line TKIs, and stayed for at least 1 year in deep molecular response, which was defined as less than 0.01 $\% B C R-A B L$ on the International Scale or undetectable $B C R-A B L$ in samples with 10,000 or more $A B L$ transcripts or 24,000 or more GUS transcripts [118].

Recurrence is presumed to arise from LSCs, which survive TKI treatment through several mechanisms [7]. Additional mutations in $B C R-A B L$ gene can confer resistance to TKIs on LSCs [119]. Moreover, BCR-ABL induces ROS generation in CP-CML cells and eventually genomic instability, which can contribute to resistance to TKIs [120] as similarly observed on BP-CML cells. CP-CML LSCs can survive TKI treatment by activating BCR-ABL-kinase-independent pathways including Hedgehog signaling [93] and ALOX5 [94]. Furthermore, bone marrow resident cells confer TKI resistance on LSCs by either promoting the interaction of LSCs with bone marrow niche [95-97] or secreting stemnessmaintaining mediators [98-103]. Nevertheless, the interaction with various types of cells present in bone marrow, is required for CML LSC maintenance.

Even in TKI era, a small number of CP-CML still progresses to AP-CML and eventually BP-CML [105]. Thus, it is necessary to identify and/or predict CP-CML patients who are at a high risk to develop AP-CML and/or BP-CML. Two scores were proposed to predict the prognosis of CP-CML patients based on the clinical findings at diagnosis $[121,122]$. Both scores utilize four parameters: blast proportions and platelet counts in peripheral blood, age, and spleen size. Moreover, the World Health Organization proposed the criteria for AP-CML: basophilia (20\% more in peripheral blood), treatmentresistant persistent leukocytosis, splenomegaly and thrombocytosis, and increased proportions of blasts in peripheral blood and bone marrow [105]. Alternatively, increases in non-stem cells such as basophils and platelets are associated with poor prognosis of CML patients and therefore, it is highly likely that leukemia non-stem cells such as basophils and megakaryocytes, a precursor of platelets, can contribute to CML pathogenesis and progression. We will discuss this assumption in detail in the following sections.

\section{Basophils in CML pathogenesis}

Basophils are the least abundant granulocytes in peripheral blood. Basophils and tissue-resident mast cells share many biological features including the presence of cytoplasmic basophilic granules, surface expression of highaffinity IgE receptor, and activation-induced release of chemical mediators, but they are distinct cell lineage differentiated from HSCs in bone marrow [123]. Human basophils develop from common basophil-eosinophil precursors, which differentiate from HSCs through the stage of common myeloid precursors [124]. In addition to basophil-eosinophil precursors, basophil-mast cell progenitors were identified in mouse but not human bone marrow, and a transcription factor, CCAAT/enhancer binding protein $(\mathrm{C} / \mathrm{EBP}) \alpha$, determined the fate of precursors to basophil differentiation [125]. IL-3 and thymic stromal lymphopoietin (TSLP) can induce bone marrow progenitors to generate basophils with distinct gene signatures [126]. Basophils and basophil-committed colony-forming units are aberrantly produced in most CML patients [127], partly due to BCR-ABL-mediated $\mathrm{C} / \mathrm{EBP} \alpha$ activation [128]. Moreover, evidence is accumulating to indicate the association of basophilia with poor prognosis in CML patients in pre-TKI $[129,130]$ and post-TKI eras [131]. Several mechanisms were proposed to explain this association.

Vessel density is increased, together with tortuous vessel architecture and augmented branching in CML bone marrow [132] and was proposed to be an independent parameter to predict worse prognosis of CML patients 
[133]. Moreover, CML patients' serum displayed enhanced levels of several angiogenic factors including vascular endothelial growth factor (VEGF) and hepatocyte growth factor (HGF) [134]. Human normal basophils contain VEGF in their secretory granules and can release it upon immunological activation [135]. BCR-ABL can induce VEGF expression in a mouse hematopoietic progenitor cell line [136], but it remains elusive on the capacity of basophil-like CML cells to secrete VEGF. Increased plasma HGF levels were associated with poor prognosis of the patients [133]. Basophil-like CML cells were identified to be a major cellular source of HGF, which could augment endothelial cell migration [137]. Additionally, basophil-like CML cells release abundantly tryptase [138], which is stored in their cytoplasm and can stimulate vascular tube formation [139]. Moreover, as tryptase is a potent mitogen for fibroblasts [140], it can contribute to the development of bone marrow fibrosis, which is associated with poor prognosis of CML patients [141] and their poor response to TKI treatment [142]. Thus, these basophil-derived mediators may be able to induce CML progression by affecting bone marrow microenvironment.

A characteristic feature of CML LSCs is their low ability to stay in bone marrow niche and their high capacity to redistribute to peripheral blood [143]. Their decreased remaining in bone marrow is associated with decreased availability of a chemokine, CXCL12, which can retain LSCs as well as normal HSCs [144]. CXCL12 can be degraded and inactivated by a surface enzyme, DPP4/CD26 [145], which is expressed by basophil-like CML cells [127] as well as CML LSCs [85]. Thus, CD26-mediated CXCL12 inactivation may account for LSC redistribution to peripheral blood. Their redistribution can be further facilitated by vascular permeability-enhancing mediators such as histamine, which is generated by the action of histidine decarboxylase expressed by basophil-like CML cells [146]. HGF can in vitro augment granulocytemacrophage (GM)-colony forming unit (CFU) formation from CML blast cells, which express Met, a specific receptor for HGF [147]. However, the pathological relevance of this observation has not been yet determined in CML models or patients.

CCL3, previously known as macrophage inflammatory protein (MIP)-1 $\alpha$, can directly inhibit normal hematopoietic stem/progenitor cell (HSPC) proliferation $[148,149]$, through the interaction with its specific receptors, CCR1 or CCR5 [150]. The transplantation of $B C R-A B L$-expressing LSCs in vivo induced aberrant CCL3 expression in bone marrow [144]. Moreover, $A B L$ gene conferred the resistance to CCL3 by abrogating CCL3-mediated intracellular calcium influx with few effects on its receptor expression [151]. These observations prompted us to investigate the role of endogenously-produced CCL3 in CML pathogenesis [152]. When BCR-ABL gene was transduced into CCL3deficient mouse-derived HSPCs to generate CML LSCs, the resultant LSCs induced CML development in irradiated hematopoiesis-incompetent mice but failed to do in un-irradiated hematopoiesis-competent mice, which preserved normal hematopoietic cells in bone marrow. Moreover, admixture with CCR1- or CCR5-deficient HSPCs blunted the leukemogenic ability of wild-type mouse-derived LSCs [152], suggesting that leukemia cell-derived CCL3 acts mainly on CCR1- or CCR5expressing normal hematopoietic cells in bone marrow to promote leukemogenesis. Given the differential effects of CCL3 on ABL-expressing and non-expressing cells [151], it is likely that CCL3 can dampen normal hematopoiesis and can reciprocally favor leukemogenic hematopoiesis (Fig. 6).

This notion has been further substantiated by our subsequent study [153]. CCL3 was expressed constitutively by normal basophils as well as basophil-like CML cells in mouse CML bone marrow, and negatively regulated normal hematopoietic process, particularly hematopoietic reconstitution after bone marrow transplantation. Depletion of basophil-like CML cells markedly reduced LSC numbers and eventually delayed CML progression [153]. Moreover, the administration of a CCR5 antagonist, maraviroc [154], prevented dramatically CML development when it was administered immediately after LSC transplantation but the effects were abrogated when administration started 2 weeks after LSC injection [153]. Thus, massively expanding basophil-like CML cells produce abundantly CCL3, which can inhibit normal hematopoiesis and can reciprocally facilitate CML LSC proliferation, particularly at the early phase, thereby advancing CML development (Fig. 6). As CCL3 was abundantly expressed by basophils in bone marrow of CML patients, it is probable that human leukemic basophils can contribute to LSC proliferation in CML.

\section{Megakaryocytes in CML pathogenesis}

Platelets have diverse impacts on development and progression of solid tumors, particularly by accelerating tumor growth through angiogenesis induction and supporting tumor cells to evade the immune system and extravasate to metastatic organs [155]. However, until present, there are no reports on the precise roles of platelets in CML pathogenesis and progression [156].

Megakaryocytes in CML exhibit atypical features such as cytoplasmic vacuolation, smaller diameter, and hetergenous distribution of cytoplasmic granules [157]. Moreover, CML megakaryocytes displayed a shift towards lower ploidy number and about $60 \%$ were less than $8 \mathrm{~N}$, compared with healthy volunteers showing the mean 


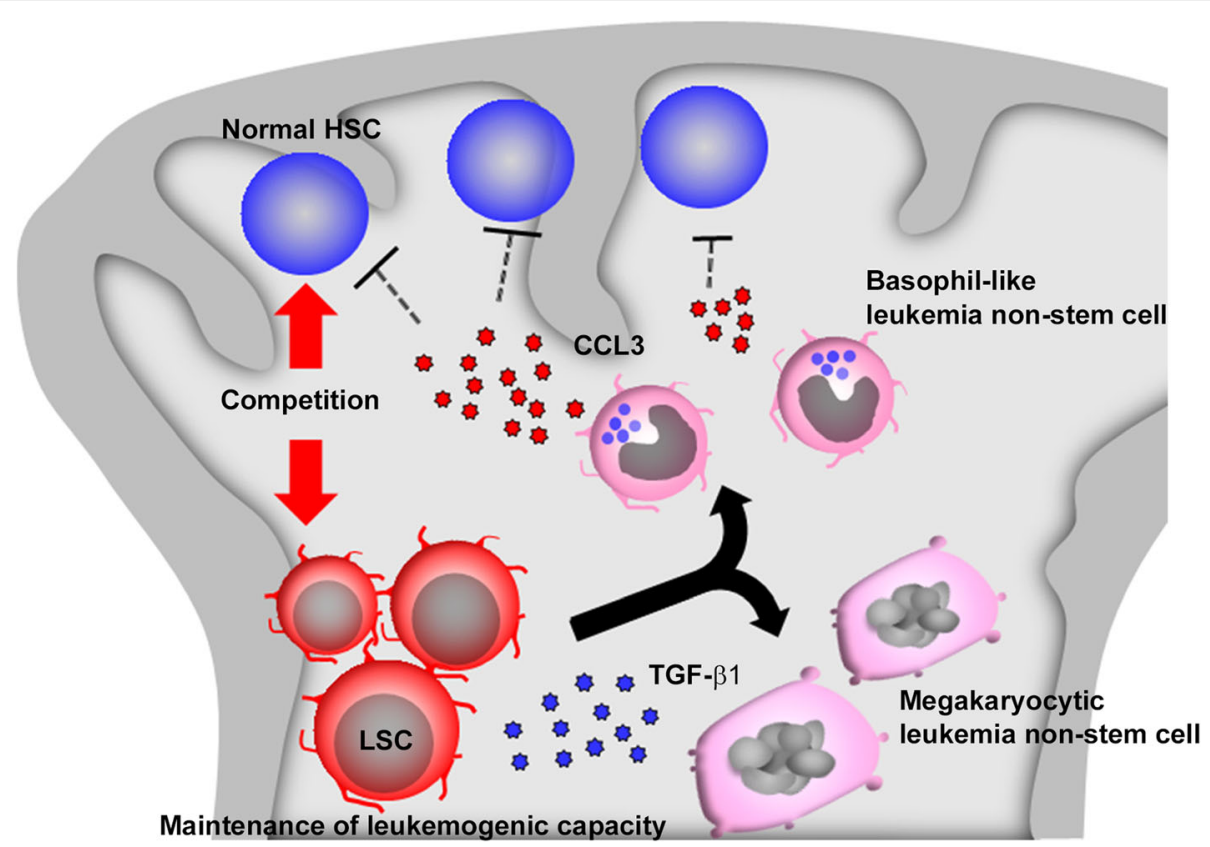

Fig. 6 Presumed roles of basophil-like and megakaryocytic leukemia non-stem cells in CML pathogenesis. LSCs massively generate basophil-like leukemia non-stem cells, which abundantly produce a chemokine, CCL3. The produced CCL3 inhibits the functions of normal HSCs which are present in a large number especially at the early phase of CML bone marrow and as a consequence, gives advantage to LSC proliferation. Concomitantly, $B C R-A B L$ gene expression induces the appearance of senescent megakaryocytic leukemia non-stem cells in bone marrow. These megakaryocytic leukemia non-stem cells abundantly produce TGF- $\beta 1$, which can sustain leukemogenic capacity of LSCs in bone marrow, thereby promoting CML propagation

modal ploidy number of $16 \mathrm{~N}$ [158, 159]. Of interest is that either interferon- $\alpha$ treatment in pre-TKI era [160] or TKI treatment [161] decreased small-sized megakaryocytes, together with improved cytogenetic response, suggesting that morphological abnormalities in megakaryocytes are closely associated with CML pathogenesis. Furthermore, in pediatric CML, increased megakaryocyte proliferation was associated with bone marrow fibrosis [162], an independent poor prognostic complication of CML [163], although it remains elusive how megakaryocyte promoted fibrosis in CML.

We recently observed that bone marrow transplantation of BCR-ABL-transduced LSCs induced massive accumulation of BCR-ABL-expressing megakaryocytes in bone marrow in CML model [164], similarly as observed on human CML patients [165]. Senescence can be induced in fibroblasts and epithelial cells by the activation of oncogenes such as Ras or B-Raf [166]. Likewise, we observed that senescence was provoked selectively in expanding megakaryocytes in CML by an oncogenic fusion protein, BCR-ABL, and was abrogated together with megakaryocyte reduction by deletion of p16 and p21 [164], the molecules crucially involved in senescence [167]. Thus, senescence may be required for megakaryocyte generation also in CML as well as that in normal hematopoiesis [168]. Senescence is frequently accompanied by senescence-associated phenotype (SASP) characterized by enhanced expression of several proinflammatory cytokines including IL-1, IL-6, CXCL8 and TGF- $\beta 1$ [169] and indeed, senescent CML megakaryocytes expressed TGF- $\beta 1$ in p16- and p21-dependent manner [164]. TGF- $\beta 1$ was proposed to contribute crucially to maintenance of CML LSCs $[99,170]$ but its cellular source has not been determined. We proved that senescent megakaryocytes were a major source of TGF- $\beta 1$ and demonstrated that p16- and p21-double-deficient LSCs failed to increase megakaryocyte numbers at the first transplantation and lacked the leukemogenic capability to cause CML development at the secondary transplantation [164]. We further revealed that bone marrow megakaryocytes in human CML patients expressed both p16 and p21, suggestive of senescence in these cells. Thus, it is likely that CML leukemia non-stem cells, BCR-ABL-transformed megakaryocytes, can support the leukemogenic capacity of CML LSCs by providing them with TGF- $\beta 1$ (Fig. 6). Moreover, as the resistance to TKIs was well correlated with bone marrow megakaryocyte numbers at diagnosis, it is highly likely that megakaryocytes can contribute to LSC maintenance in human CML patients.

\section{Perspective on the roles of cancer non-stem cells in solid tumors}

CSCs are presently presumed to be crucially involved in malignant progression of solid cancer: chemoresistance, 
radioresistance, immune evasion, and metastasis. Apparent morphological differences enabled us to identify non-stem cells such as basophils and megakaryocytes in CML. Basophil-derived CCL3 favors LSC-mediated hematopoiesis by suppressing normal hematopoiesis while megakaryocyte-derived TGF- $\beta 1$ maintains the stemness of LSCs. Thus, leukemia non-stem cells have indispensable roles in the proliferation and maintenance of LSCs in CML. A similar observation was observed on glioblastoma, a representative solid cancer, which arises from CSCs $[9,10]$. Bastola and colleagues demonstrated that CSCs were enriched at tumor edge compared to tumor core sites of GBM tissues and that the cells at core sites released soluble CD109 to induce CSCs at tumor edge to proliferate and to display radioresistance [171]. Thus, even in solid cancer, cancer non-stem cells may contribute to cancer development and progression as in the case of CML. However, more elaborate methods are required to be developed to discriminate precisely cancer non-stem cells from CSCs, for extensive clarification on the roles of cancer non-stem cells in cancer development and progression.

\begin{abstract}
Abbreviations
ABC: ATP-binding cassette; $A B C B 1$ : $A B C$ subfamily-B member 1; $A B C G 2: A B C$ subfamily-G member 2; AP: Accelerated phase; ALDH: Aldehyde dehydrogenase; AML: Acute myeloid leukemia; ATM: Ataxia-telangiectasiamutated; Bcl-2: B-cell lymphoma 2; BC: Blast crisis; bFGF: Basic fibroblast growth factor; BMP: Bone morphogenic protein; CAF: Cancer-associated fibroblast; CD44s: Standard form of CD44; CD44v: Variant CD44 isoform; CEBP: CCAAT/enhancer binding protein; CFU: Colony-forming unit; ch: Chromosome; CML: Chronic myeloid leukemia; CP: Chronic phase; CSC: Cancer stem cell; DPP: Dipeptidyl peptidase; EMT: Epithelialmesenchymal transition; GM: Granulocyte-macrophage; HGF: Hepatocyte growth factor; HIF: Hypoxia inducible factor; HPC: Hematopoietic progenitor cell; HSC: Hematopoietic stem cell; HSPC: Hematopoietic stem/progenitor cell; IL: Interleukin; JAK: Janus kinase; LSC: Leukemia stem cell; MIP: Macrophage inflammatory protein; NF-KB: Nuclear factor- KB; NK: Natural killer; PI3K: Phosphoinositide 3-kinase; ROS: Reactive oxygen species; SASP: Senescence-associated secretory phenotype; SP: Side population; SRB2: Scavenger receptor-B2; STAT: Signal transducer and activator of transcription; TGF: Transforming growth factor; TKl: Tyrosine kinase inhibitor; Treg: Regulatory T cell; TSLP: Thymic stromal lymphopoietin; VEGF: Vascular endothelial growth factor
\end{abstract}

\section{Acknowledgements}

This work is partially supported by Grant-in-Aid for Scientific Research (C) from Japan Society for the Promotion of Science and by Extramural Collaborative Grant of Cancer Research Institute, Kanazawa University.

\section{Code availability}

Not applicable.

\section{Authors' contributions}

NM and TB conceptualized manuscript and wrote the manuscript. YT contributed to the conceptualization through active discussion with NM. YT and BT drew Figures. The author(s) read and approved the final manuscript.

\section{Funding}

This work is partially supported by Grant-in-Aid for Scientific Research (C) from Japan Society for the Promotion of Science and by Extramural Collaborative Grant of Cancer Research Institute, Kanazawa University.
Availability of data and materials

Not applicable.

\section{Ethics Approval and Consent to participate}

All the data obtained from our experiments were approved by local ethics committees on clinical studies and animal experiments.

All authors concur to submit this article.

\section{Consent for publication}

All authors concur to publish this article.

\section{Competing Interests}

We declare no conflict of interests.

Received: 1 December 2020 Accepted: 17 February 2021

Published online: 10 March 2021

\section{References}

1. Baillie-Benson P, Moris N, Martinez AA. Pluripotent stem cell models of early mammalian development. Curr Opin Cell Biol. 2020;66:89-96. https://doi. org/10.1016/j.ceb.2020.05.010.

2. Fuchs E, Blau HM. Tissue stem Cells: Architects of their niches. Cell Stem Cell. 2020;27(4):532-56. https://doi.org/10.1016/j.stem.2020.09.011.

3. Shapira SN, Christofk HR. Metabolic regulation of tissue stem cells. Trends Cell Biol. 2020;30(7):566-76. https://doi.org/10.1016/j.tcb.2020.04.004.

4. Clarkson B, Ohkita T, Ota K, Fried J. Studies of cellular proliferation in human leukemia. I. Estimation of growth rates of leukemic and normal hematopoietic cells in two adults with acute leukemia given single injections of tritiated thymidine. J Clin Invest. 1967;46(4):506-29. https://doi. org/10.1172/JCl105553.

5. Lapidot T, Sirard C, Vormoor J, Murdoch B, Hoang T, Caceres-Cortes J, et al. A cell initiating human acute myeloid leukaemia after transplantation into SCID mice. Nature. 1994;367(6464):645-8. https://doi.org/10.1038/367645a0.

6. Bonnet D, Dick JE. Human acute myeloid leukemia is organized as a hierarchy that originates from a primitive hematopoietic cell. Nat Med. 1997:3(7):730-7. https://doi.org/10.1038/nm0797-730.

7. Vetrie D, Helgason GV, Copland M. The leukaemia stem cell: similarities, differences and clinical prospects in CML and AML. Nat Rev Cancer. 2020; 20(3):158-73. https://doi.org/10.1038/s41568-019-0230-9.

8. Al-Hajj M, Wicha MS, Benito-Hernandez A, Morrison SJ, Clarke MF. Prospective identification of tumorigenic breast cancer cells. Proc Natl Acad Sci USA. 2003;100(7):3983-8. https://doi.org/10.1073/pnas.0530291100.

9. Singh SK, Clarke ID, Terasaki M, Bonn VE, Hawkins C, Squire J, et al. Identification of a cancer stem cell in human brain tumors. Cancer Res. 2003:63(18):5821-8.

10. Singh SK, Hawkins C, Clarke ID, Squire JA, Bayani J, Hide T, et al. Identification of human brain tumour initiating cells. Nature. 2004:432(7015): 396-401. https://doi.org/10.1038/nature03128.

11. Dalerba P, Dylla SJ, Park IK, Liu R, Wang X, Cho RW, et al. Phenotypic characterization of human colorectal cancer stem cells. Proc Natl Acad Sci USA. 2007;104(24):10158-63. https://doi.org/10.1073/pnas.0703478104.

12. Chiba T, Kita K, Zheng YW, Yokosuka O, Saisho H, Iwama A, et al. Side population purified from hepatocellular carcinoma cells harbors cancer stem cell-like properties. Hepatol. 2006;44(1):240-51. https://doi.org/10.1002/ hep.21227.

13. Li C, Heidt DG, Dalerba P, Burant CF, Zhang L, Adsay V, et al. Identification of pancreatic cancer stem cells. Cancer Res. 2007;67(3):1030-7. https://doi. org/10.1158/0008-5472.can-06-2030.

14. Quintana E, Shackleton M, Sabel MS, Fullen DR, Johnson TM, Morrison SJ. Efficient tumour formation by single human melanoma cells. Nature. 2008; 456(7222):593-8. https://doi.org/10.1038/nature07567.

15. Bajaj J, Diaz E, Reya T. Stem cells in cancer initiation and progression. J Cell Biol. 2020;219(1). https://doi.org/10.1083/jcb.201911053.

16. Atashzar MR, Baharlou R, Karami J, Abdollahi H, Rezaei R, Pourramezan F, et al. Cancer stem cells: A review from origin to therapeutic implications. $J$ Cell Physiol. 2020;235(2):790-803. https://doi.org/10.1002/jcp.29044.

17. Vermeulen L, De Sousa EMF, Van Der Heijden M, Cameron K, De Jong JH, Borovski T, et al. Wnt activity defines colon cancer stem cells and is regulated by the microenvironment. Nat Cell Biol. 2010;12(5):468-76. https:// doi.org/10.1038/ncb2048. 
18. Jang GB, Kim JY, Cho SD, Park KS, Jung JY, Lee HY, et al. Blockade of Wnt/ $\beta$ catenin signaling suppresses breast cancer metastasis by inhibiting CSC-like phenotype. Sci Rep. 2015;5. https://doi.org/10.1038/srep12465.

19. Zbinden M, Duquet A, Lorente-Trigos A, Ngwabyt SN, Borges I, Ruiz I, Altaba A. NANOG regulates glioma stem cells and is essential in vivo acting in a cross-functional network with GLI1 and p53. EMBO J. 2010;29(15):2659-74. https://doi.org/10.1038/emboj.2010.137.

20. Hallahan AR, Pritchard Jl, Hansen S, Benson M, Stoeck J, Hatton BA, et al. The SmoA1 mouse model reveals that notch signaling is critical for the growth and survival of Sonic Hedgehog-induced medulloblastomas. Cancer Res. 2004;64(21):7794-800. https://doi.org/10.1158/0008-5472.CAN-04-1813.

21. Barker N, Ridgway RA, Van Es JH, Van De Wetering M, Begthel H, Van Den Born $M$, et al. Crypt stem cells as the cells-of-origin of intestinal cancer. Nature. 2009;457(7229):608-11. https://doi.org/10.1038/nature07602.

22. Wang GY, Wang J, Mancianti ML, Epstein EH Jr. Basal cell carcinomas arise from hair follicle stem cells in Ptch1(+/-) mice. Cancer Cell. 2011;19(1):11424. https://doi.org/10.1016/j.ccr.2010.11.007.

23. Tomasetti C, Vogelstein B. Variation in cancer risk among tissues can be explained by the number of stem cell divisions. Science. 2015;347(6217):7881. https://doi.org/10.1126/science.1260825.

24. Cozzio A, Passegué E, Ayton PM, Karsunky H, Cleary ML, Weissman IL. Similar MLL-associated leukemias arising from self-renewing stem cells and shortlived myeloid progenitors. Gees Dev. 2003;17(24):3029-35. https://doi.org/1 $0.1101 / \mathrm{gad} .1143403$

25. Huntly BJP, Shigematsu H, Deguchi K, Lee BH, Mizuno S, Duclos N, et al. MOZ-TIF2, but not BCR-ABL, confers properties of leukemic stem cells to committed murine hematopoietic progenitors. Cancer Cell. 2004;6(6):58796. https://doi.org/10.1016/j.ccr.2004.10.015.

26. Koren S, Reavie L, Couto JP, De Silva D, Stadler MB, Roloff T, et al. PIK3CAH1047R induces multipotency and multi-lineage mammary tumours. Nature. 2015;525(7567):114-8. https://doi.org/10.1038/nature14669.

27. Liang Y, Zhong Z, Huang Y, Deng W, Cao J, Tsao G, et al. Stem-like cancer cells are inducible by increasing genomic instability in cancer cells. J Biol Chem. 2010;285(7):4931-40. https://doi.org/10.1074/jbc.M109.048397.

28. Lluis F, Cosma MP. Cell-fusion-mediated somatic-cell reprogramming: a mechanism for tissue regeneration. J Cell Physiol. 2010;223(1):6-13. https:// doi.org/10.1002/jcp.22003.

29. Duelli D, Lazebnik Y. Cell fusion: a hidden enemy? Cancer Cell. 2003;3(5): 445-8. https://doi.org/10.1016/s1535-6108(03)00114-4.

30. Gauck D, Keil S, Niggemann B, Zänker KS, Dittmar T. Hybrid clone cells derived from human breast epithelial cells and human breast cancer cells exhibit properties of cancer stem/initiating cells. BMC Cancer. 2017;17(1): 515. https://doi.org/10.1186/s12885-017-3509-9.

31. Chan YW, So C, Yau KL, Chiu KC, Wang X, Chan FL, et al. Adipose-derived stem cells and cancer cells fuse to generate cancer stem cell-like cells with increased tumorigenicity. J Cell Physiol. 2020;235(10):6794-807. https://doi. org/10.1002/jcp.29574

32. Krishnamurthy S, Dong Z, Vodopyanov D, Imai A, Helman Jl, Prince ME, et al. Endothelial cell-initiated signaling promotes the survival and selfrenewal of cancer stem cells. Cancer Res. 2010;70(23):9969-78. https://doi. org/10.1158/0008-5472.CAN-10-1712.

33. Krishnamurthy S, Warner KA, Dong Z, Imai A, Nör C, Ward BB, et al. Endothelial interleukin- 6 defines the tumorigenic potential of primary human cancer stem cells. Stem Cells. 2014;32(11):2845-57. https://doi.org/1 $0.1002 /$ stem.1793.

34. Fessler E, Borovski T, Medema JP. Endothelial cells induce cancer stem cell features in differentiated glioblastoma cells via bFGF. Mol Cancer. 2015; 14(1). https://doi.org/10.1186/s12943-015-0420-3.

35. Liao CP, Adisetiyo H, Liang M, Roy-Burman P. Cancer-associated fibroblasts enhance the gland-forming capability of prostate cancer stem cells. Cance Res. 2010;70(18):7294-303. https://doi.org/10.1158/0008-5472.CAN-09-3982.

36. Tsuyada A, Chow A, Wu J, Somlo G, Chu P, Loera S, et al. CCL2 mediates cross-talk between cancer cells and stromal fibroblasts that regulates breast cancer stem cells. Cancer Res. 2012;72(11):2768-79. https://doi.org/10.1158/ 0008-5472.CAN-11-3567.

37. Balamurugan K. HIF-1 at the crossroads of hypoxia, inflammation, and cancer. Int J Cancer. 2016;138(5):1058-66. https://doi.org/10.1002/ijc.29519.

38. Soleymani Abyaneh H, Gupta N, Alshareef A, Gopal K, Lavasanifar A, Lai R. Hypoxia induces the acquisition of cancer stem-like phenotype via upregulation and activation of signal transducer and activator of transcription-3 (STAT3) in MDA-MB-231, a triple negative breast cancer cell line. Cancer Microenviron. 2018;11(2):141-52. https://doi.org/10.1007/s123 07-018-0218-0.

39. Sansone P, Berishaj M, Rajasekhar VK, Ceccarelli C, Chang Q, Strillacci A, et al Evolution of cancer stem-like cells in endocrine-resistant metastatic breast cancers is mediated by stromal microvesicles. Cancer Res. 2017;77(8):192741. https://doi.org/10.1158/0008-5472.CAN-16-2129.

40. Korkaya H, Liu S, Wicha MS. Regulation of cancer stem cells by cytokine networks: Attacking cancer's inflammatory roots. Clin Cancer Res. 2011; 17(19):6125-8. https://doi.org/10.1158/1078-0432.CCR-10-2743.

41. Mani SA, Guo W, Liao MJ, Eaton EN, Ayyanan A, Zhou AY, et al. The epithelial-mesenchymal transition generates cells with properties of stem cells. Cell. 2008;133(4):704-15. https://doi.org/10.1016/j.cell.2008.03.027.

42. Hong D, Fritz AJ, Zaidi SK, van Wijnen AJ, Nickerson JA, Imbalzano AN, et al. Epithelial-to-mesenchymal transition and cancer stem cells contribute to breast cancer heterogeneity. J Cell Physiol. 2018;233(12):9136-44. https://doi. org/10.1002/jcp.26847.

43. Yeung KT, Yang J. Epithelial-mesenchymal transition in tumor metastasis. Mol Oncol. 2017;11(1):28-39. https://doi.org/10.1002/1878-0261.12017.

44. Walcher L, Kistenmacher AK, Suo H, Kitte R, Dluczek S, Strauß A, et al. Cancer stem cells_-Origins and biomarkers: Perspectives for targeted personalized therapies. Front Immunol. 2020;11. https://doi.org/10.3389/ fimmu.2020.01280.

45. Prochazka $L$, Tesarik $R$, Turanek J. Regulation of alternative splicing of CD44 in cancer. Cell Signal. 2014;26(10):2234-9. https://doi.org/10.1016/j.cellsig.2 014.07.011.

46. Aghajani M, Mansoori B, Mohammadi A, Asadzadeh Z, Baradaran B. New emerging roles of CD133 in cancer stem cell: Signaling pathway and miRNA regulation. J Cell Physiol. 2019;234(12):21642-61. https://doi.org/10.1002/ jcp.28824.

47. Skandalis SS, Karalis TT, Chatzopoulos A, Karamanos NK. Hyaluronan-CD44 axis orchestrates cancer stem cell functions. Cell Signal. 2019;63:109377. https://doi.org/10.1016/j.cellsig.2019.109377.

48. Miraglia S, Godfrey W, Yin AH, Atkins K, Warnke R, Holden JT, et al. A nove five-transmembrane hematopoietic stem cell antigen: isolation, characterization, and molecular cloning. Blood. 1997;90(12):5013-21.

49. Yoshida A, Rzhetsky A, Hsu LC, Chang C. Human aldehyde dehydrogenase gene family. Eur J Biochem. 1998;251(3):549-57. https://doi.org/10.1046/ j.1432-1327.1998.2510549.x

50. Chute JP, Muramoto GG, Whitesides J, Colvin M, Safi R, Chao NJ, et al. Inhibition of aldehyde dehydrogenase and retinoid signaling induces the expansion of human hematopoietic stem cells. Proc Natl Acad Sci USA. 2006;103(31):11707-12. https://doi.org/10.1073/pnas.0603806103.

51. Ginestier C, Hur MH, Charafe-Jauffret E, Monville F, Dutcher J, Brown M, et al. ALDH1 is a marker of normal and malignant human mammary stem cells and a predictor of poor clinical outcome. Cell Stem Cell. 2007;1(5):55567. https://doi.org/10.1016/j.stem.2007.08.014.

52. Deng $S$, Yang $X$, Lassus $H$, Liang $S$, Kaur $S$, Ye Q, et al. Distinct expression levels and patterns of stem cell marker, aldehyde dehydrogenase isoform 1 (ALDH1), in human epithelial cancers. PloS One. 2010:5(4). https://doi.org/1 0.1371/journal.pone.0010277

53. Huang EH, Hynes MJ, Zhang T, Ginestier C, Dontu G, Appelman H, et al. Aldehyde dehydrogenase 1 is a marker for normal and malignant human colonic stem cells (SC) and tracks SC overpopulation during colon tumorigenesis. Cancer Res. 2009;69(8):3382-9. https://doi.org/10.1158/00085472.CAN-08-4418.

54. Sun S, Wang Z. ALDHhigh adenoid cystic carcinoma cells display cancer stem cell properties and are responsible for mediating metastasis. Biochem Biophys Res Commun. 2010;396(4):843-8. https://doi.org/10.1016/j.bbrc.201 0.04.170.

55. Begicevic RR, Falasca M. ABC transporters in cancer stem cells: Beyond chemoresistance. Int J Mol Sci. 2017;18(11). https://doi.org/10.3390/ijms1 8112362.

56. Hadnagy A, Gaboury L, Beaulieu R, Balicki D. SP analysis may be used to identify cancer stem cell populations. Exp Cell Res. 2006:312(19):3701-10. https://doi.org/10.1016/j.yexcr.2006.08.030

57. Steinbichler TB, Dudás J, Skvortsov S, Ganswindt U, Riechelmann H, Skvortsova II. Therapy resistance mediated by cancer stem cells. Semin Cancer Biol. 2018;53:156-67. https://doi.org/10.1016/j.semcancer.2018.11.006.

58. Müller L, Tunger A, Plesca I, Wehner R, Temme A, Westphal D, et al. Bidirectional crosstalk between cancer stem cells and immune cell subsets. Front Immunol. 2020;11. https://doi.org/10.3389/fimmu.2020.00140. 
59. Nimmakayala RK, Batra SK, Ponnusamy MP. Unraveling the journey of cancer stem cells from origin to metastasis. Bioch Biophys Acta Rev Cancer. 2019;1871(1):50-63. https://doi.org/10.1016/j.bbcan.2018.10.006.

60. van Velthoven CTJ, Rando TA. Stem cell quiescence: Dynamism, restraint, and cellular idling. Cell Stem Cell. 2019;24(2):213-25. https://doi.org/10.1016/ j.stem.2019.01.001.

61. De Angelis ML, Francescangeli F, La Torre F, Zeuner A. Stem cell plasticity and dormancy in the development of cancer therapy resistance. Front Oncol. 2019;9(JULY). https://doi.org/10.3389/fonc.2019.00626.

62. Crea F, Nur Saidy NR, Collins CC, Wang Y. The epigenetic/noncoding origin of tumor dormancy. Trends Mol Med. 2015;21(4):206-11. https://doi.org/10.1 016/j.molmed.2015.02.005.

63. Kontos CK, Christodoulou MI, Scorilas A. Apoptosis-related BCL2-family members: Key players in chemotherapy. Anticancer Agents Med Chem. 2014;14(3):353-74. https://doi.org/10.2174/18715206113139990091.

64. Domingo-Domenech J, Vidal SJ, Rodriguez-Bravo V, Castillo-Martin M, Quinn S, Rodriguez-Barrueco R, et al. Suppression of acquired docetaxel resistance in prostate cancer through depletion of Notch- and Hedgehog-dependent tumor-initiating cells. Cancer Cell. 2012;22(3):373-88. https://doi.org/10.1016/ j.ccr.2012.07.016.

65. Lang JY, Hsu J, Meric-Bernstam F, Chang CJ, Wang Q, Bao Y, et al. BikDD eliminates breast cancer initiating cells and synergizes with lapatinib for breast cancer treatment. Cancer Cell. 2011;20(3):341-56. https://doi.org/10.1 016/j.ccr.2011.07.017

66. Chen Z, Shi T, Zhang L, Zhu P, Deng M, Huang C, et al. Mammalian drug efflux transporters of the ATP binding cassette $(A B C)$ family in multidrug resistance: A review of the past decade. Cancer Lett. 2016;370(1):153-64. https://doi.org/10.1016/j.canlet.2015.10.010.

67. Diehn M, Cho RW, Lobo NA, Kalisky T, Dorie MJ, Kulp AN, et al. Association of reactive oxygen species levels and radioresistance in cancer stem cells. Nature. 2009;458(7239):780-3. https://doi.org/10.1038/nature07733.

68. Bao S, Wu Q, McLendon RE, Hao Y, Shi Q, Hjelmeland AB, et al. Glioma stem cells promote radioresistance by preferential activation of the DNA damage response. Nature. 2006:444(7120):756-60. https://doi.org/10.1038/nature0523 6.

69. Guo X, Zhao Y, Yan H, Yang Y, Shen S, Dai X, et al. Single tumor-initiating cells evade immune clearance by recruiting type II macrophages. Genes Dev. 2017:31(3):247-59. https://doi.org/10.1101/gad.294348.116.

70. Schatton T, Schütte U, Frank NY, Zhan Q, Hoerning A, Robles SC, et al. Modulation of T-cell activation by malignant melanoma initiating cells. Cancer Res. 2010;70(2):697-708. https://doi.org/10.1158/0008-5472.can-09-1 592.

71. Wei J, Barr J, Kong LY, Wang Y, Wu A, Sharma AK, et al. Glioma-associated cancer-initiating cells induce immunosuppression. Clin Cancer Res. 2010; 16(2):461-73. https://doi.org/10.1158/1078-0432.ccr-09-1983.

72. Hsu J-M, Xia W, Hsu Y-H, Chan L-C, Yu W-H, Cha J-H, et al. STT3-dependent PD-L1 accumulation on cancer stem cells promotes immune evasion. Nat Commun. 2018;9(1):1908. https://doi.org/10.1038/s41467-018-04313-6.

73. Liu L, Zhang L, Yang L, Li H, Li R, Yu J, et al. Anti-CD47 antibody as a targeted therapeutic agent for human lung cancer and cancer stem cells. Front Immunol. 2017;8(APR). https://doi.org/10.3389/fimmu.2017.00404.

74. Morrison BJ, Steel JC, Morris JC. Reduction of MHC-I expression limits Tlymphocyte-mediated killing of Cancer-initiating cells. BMC Cancer. 2018; 18(1). https://doi.org/10.1186/s12885-018-4389-3.

75. Paczulla AM, Rothfelder K, Raffel S, Konantz M, Steinbacher J, Wang H, et al. Absence of NKG2D ligands defines leukaemia stem cells and mediates their immune evasion. Nature. 2019;572(7768):254-9. https://doi.org/10.1038/s41 586-019-1410-1.

76. Charafe-Jauffret E, Ginestier C, lovino F, Wicinski J, Cervera N, Finetti P, et al. Breast cancer cell lines contain functional cancer stem sells with metastatic capacity and a distinct molecular signature. Cancer Res. 2009;69(4):1302-13. https://doi.org/10.1158/0008-5472.CAN-08-2741.

77. Gkountela S, Castro-Giner F, Szczerba BM, Vetter M, Landin J, Scherrer R, et al. Circulating tumor cell clustering shapes DNA methylation to enable metastasis seeding. Cell. 2019;176(1-2):98-112.e14. https://doi.org/10.1016/j. cell.2018.11.046

78. Holyoake TL, Vetrie D. The chronic myeloid leukemia stem cell: stemming the tide of persistence. Blood. 2017;129(12):1595-606. https://doi.org/10.11 82/blood-2016-09-696013.

79. Wang JY. The capable ABL: what is its biological function? Mol Cell Biol. 2014;34(7):1188-97. https://doi.org/10.1128/mcb.01454-13.
80. Daley GQ, Van Etten RA, Baltimore D. Induction of chronic myelogenous leukemia in mice by the P210 bcr/abl gene of the Philadelphia chromosome. Science. 1990;247(4944):824-30. https://doi.org/10.1126/ science. 2406902

81. Koschmieder S, Gottgens B, Zhang P, Iwasaki-Arai J, Akashi K, Kutok JL, et al. Inducible chronic phase of myeloid leukemia with expansion of hematopoietic stem cells in a transgenic model of BCR-ABL leukemogenesis. Blood. 2005;105(1):324-34. https://doi.org/10.1182/blood-2 003-12-4369.

82. Foley Samantha B, Hildenbrand Zacariah L, Soyombo Abigail A, Magee Jeffery A, Wu Y, Oravecz-Wilson Katherine I, et al. Expression of BCR/ABL p210 from a knockin allele enhances bone marrow engraftment without inducing neoplasia. Cell Rep. 2013;5(1):51-60. https://doi.org/10.1016/j. celrep.2013.08.037

83. Jiang X, Zhao Y, Smith C, Gasparetto M, Turhan A, Eaves A, et al. Chronic myeloid leukemia stem cells possess multiple unique features of resistance to BCR-ABL targeted therapies. Leukemia. 2007;21(5):926-35. https://doi. org/10.1038/sj.leu.2404609

84. Corbin AS, Agarwal A, Loriaux M, Cortes J, Deininger MW, Druker BJ. Human chronic myeloid leukemia stem cells are insensitive to imatinib despite inhibition of BCR-ABL activity. J Clin Invest. 2011;121(1):396-409. https://doi. org/10.1172/JCl35721.

85. Herrmann H, Sadovnik I, Cerny-Reiterer S, Rülicke T, Stefanzl G, Willmann M, et al. Dipeptidylpeptidase IV (CD26) defines leukemic stem cells (LSC) in chronic myeloid leukemia. Blood. 2014;123(25):3951-62. https://doi.org/1 0.1182/blood-2013-10-536078.

86. Sadovnik I, Hoelbl-Kovacic A, Herrmann H, Eisenwort G, Cerny-Reiterer S, Warsch W, et al. Identification of CD25 as STAT5-dependent growth regulator of leukemic stem cells in $\mathrm{Ph}^{+}$CML. Clin Cancer Res. 2016;22(8): 2051-61. https://doi.org/10.1158/1078-0432.ccr-15-0767.

87. Landberg N, von Palffy S, Askmyr M, Lilljebjörn H, Sandén C, Rissler M, et al. CD36 defines primitive chronic myeloid leukemia cells less responsive to imatinib but vulnerable to antibody-based therapeutic targeting. Haematologica. 2018;103(3):447-55. https://doi.org/10.3324/haematol.2017.1 69946.

88. Landberg N, Hansen N, Askmyr M, Ågerstam H, Lassen C, Rissler M, et al. IL1RAP expression as a measure of leukemic stem cell burden at diagnosis of chronic myeloid leukemia predicts therapy outcome. Leukemia. 2016; 30(1):255-8. https://doi.org/10.1038/leu.2015.135.

89. Pellicano F, Scott MT, Helgason GV, Hopcroft LEM, Allan EK, Aspinall-O'Dea $M$, et al. The antiproliferative activity of kinase inhibitors in chronic myeloid leukemia cells is mediated by FOXO transcription factors. Stem cells. 2014; 32(9):2324-37. https://doi.org/10.1002/stem.1748.

90. Heidel FH, Bullinger L, Feng Z, Wang Z, Neff TA, Stein L, et al. Genetic and pharmacologic inhibition of $\beta$-catenin targets imatinib-resistant leukemia stem cells in CML. Cell Stem Cell. 2012;10(4):412-24. https://doi.org/10.1016/ j.stem.2012.02.017.

91. Riether $C$, Schürch CM, Flury C, Hinterbrandner M, Drück L, Huguenin AL, et al. Tyrosine kinase inhibitor-induced CD70 expression mediates drug resistance in leukemia stem cells by activating Wnt signaling. Sci Transl Med. 2015;7(298). https://doi.org/10.1126/scitranslmed.aab1740.

92. Valent P. Targeting the JAK2-STAT5 pathway in CML. Blood. 2014;124(9): 1386-8. https://doi.org/10.1182/blood-2014-07-585943.

93. Zhao C, Chen A, Jamieson CH, Fereshteh M, Abrahamsson A, Blum J, et al. Hedgehog signalling is essential for maintenance of cancer stem cells in myeloid leukaemia. Nature. 2009;458(7239):776-9. https://doi.org/10.1038/na ture07737.

94. Chen $Y$, Hu Y, Zhang H, Peng C, Li S. Loss of the Alox5 gene impairs leukemia stem cells and prevents chronic myeloid leukemia. Nat Genet. 2009;41(7):783-92. https://doi.org/10.1038/ng.389.

95. Eiring AM, Khorashad JS, Anderson DJ, Yu F, Redwine HM, Mason CC, et al. $\beta$-Catenin is required for intrinsic but not extrinsic BCR-ABL1 kinase-independent resistance to tyrosine kinase inhibitors in chronic myeloid leukemia. Leukemia. 2015;29(12):2328-37. https://doi.org/10.103 8/leu.2015.196.

96. Krause DS, Lazarides K, Von Andrian UH, Van Etten RA. Requirement for CD44 in homing and engraftment of BCR-ABL-expressing leukemic stem cells. Nat Med. 2006;12(10):1175-80. https://doi.org/10.1038/nm1489.

97. Yamamoto-Sugitani M, Kuroda J, Ashihara E, Nagoshi H, Kobayashi T, Matsumoto Y, et al. Galectin-3 (Gal-3) induced by leukemia microenvironment promotes drug resistance and bone marrow lodgment 
in chronic myelogenous leukemia. Proc Natl Acad Sci USA. 2011;108(42): 17468-73. https://doi.org/10.1073/pnas.1111138108.

98. Sengupta A, Banerjee D, Chandra S, Banerji SK, Ghosh R, Roy R, et al. Deregulation and cross talk among Sonic hedgehog, Wnt, Hox and Notch signaling in chronic myeloid leukemia progression. Leukemia. 2007;21(5): 949-55. https://doi.org/10.1038/sj.leu.2404657.

99. Naka K, Hoshii T, Muraguchi T, Tadokoro Y, Ooshio T, Kondo Y, et al. TGF-[bgr]FOXO signalling maintains leukaemia-initiating cells in chronic myeloid leukaemia. Nature. 2010;463(7281):676-80. https:/doi.org/10.1038/nature08734.

100. Toofan P, Busch C, Morrison H, O'Brien S, Jørgensen H, Copland M, et al. Chronic myeloid leukaemia cells require the bone morphogenic protein pathway for cell cycle progression and self-renewal. Cell Death Dis. 2018; 9(9). https://doi.org/10.1038/s41419-018-0905-2.

101. Tabe Y, Jin L, Iwabuchi K, Wang RY, Ichikawa N, Miida T, et al. Role of stromal microenvironment in nonpharmacological resistance of CML to imatinib through Lyn/CXCR4 interactions in lipid rafts. Leukemia. 2012;26(5): 883-92. https://doi.org/10.1038/leu.2011.291

102. Ågerstam H, Hansen N, Von Palffy S, Sanden C, Reckzeh K, Karlsson C, et al. IL1RAP antibodies block IL-1-induced expansion of candidate CML stem cells and mediate cell killing in xenograft models. Blood. 2016;128(23):268393. https://doi.org/10.1182/blood-2015-11-679985.

103. Zhang B, Nguyen LXT, Li L, Zhao D, Kumar B, Wu H, et al. Bone marrow niche trafficking of miR-126 controls the self-renewal of leukemia stem cells in chronic myelogenous leukemia. Nat Med. 2018;24(4):450-62. https://doi. org/10.1038/nm.4499.

104. Hochhaus A, Baccarani M, Silver RT, Schiffer C, Apperley JF, Cervantes F, et al. European LeukemiaNet 2020 recommendations for treating chronic myeloid leukemia. Leukemia. 2020;34(4):966-84. https://doi.org/10.1038/s413 75-020-0776-2.

105. Arber DA, Orazi A, Hasserjian R, Thiele J, Borowitz MJ, Le Beau MM, et al. The 2016 revision to the World Health Organization classification of myeloid neoplasms and acute leukemia. Blood. 2016;127(20):2391-405. https://doi. org/10.1182/blood-2016-03-643544.

106. Saußele S, Silver RT. Management of chronic myeloid leukemia in blast crisis. Ann Hematol. 2015;94(Suppl 2):S159-65. https://doi.org/10.1007/s002 77-015-2324-0

107. Slupianek A, Poplawski T, Jozwiakowski SK, Cramer K, Pytel D, Stoczynska E, et al. BCR/ABL stimulates WRN to promote survival and genomic instability. Cancer Res. 2011;71(3):842-51. https://doi.org/10.1158/0008-5472.CAN-10-1066.

108. Sill H, Goldman JM, Cross NCP. Homozygous deletions of the p16 tumorsuppressor gene are associated with lymphoid transformation of chronic myeloid leukemia. Blood. 1995;85(8):2013-6. https://doi.org/10.1182/blood. v85.8.2013.bloodjournal8582013.

109. Feinstein E, Cimino G, Gale RP, Alimena G, Berthier R, Kishi K, et al. p53 in chronic myelogenous leukemia in acute phase. Proc Natl Acad Sci USA. 1991;88(14):6293-7. https://doi.org/10.1073/pnas.88.14.6293.

110. Towatari M, Adachi K, Kato H, Saito H. Absence of the human retinoblastoma gene product in the megakaryoblastic crisis of chronic myelogenous leukemia. Blood. 1991;78(9):2178-81. https://doi.org/10.1182/ blood.v78.9.2178.2178.

111. Ogawa S, Kurokawa M, Tanaka T, Tanaka K, Hangaishi A, Mitani K, et al. Increased Evi-1 expression is frequently observed in blastic crisis of chronic myelocytic leukemia. Leukemia. 1996;10(5):788-94.

112. Grossmann V, Kohlmann A, Zenger M, Schindela S, Eder C, Weissmann S, et al. A deep-sequencing study of chronic myeloid leukemia patients in blast crisis (BC-CML) detects mutations in 76.9\% of cases. Leukemia. 2011; 25(3):557-60. https://doi.org/10.1038/leu.2010.298.

113. Brusa G, Zuffa E, Mancini M, Benvenuti M, Calonghi N, Barbieri E, et al. P210 Bcr-abl tyrosine kinase interaction with histone deacetylase 1 modifies histone $\mathrm{H} 4$ acetylation and chromatin structure of chronic myeloid leukaemia haematopoietic progenitors. Br J Haematol. 2006;132(3):359-69. https://doi.org/10.1111/j.1365-2141.2005.05873.x

114. Hattori A, Tsunoda M, Konuma T, Kobayashi M, Nagy T, Glushka J, et al. Cancer progression by reprogrammed BCAA metabolism in myeloid leukaemia. Nature. 2017;545(7655):500-4. https://doi.org/10.1038/na ture22314.

115. Hochhaus A, Larson RA, Guilhot F, Radich JP, Branford S, Hughes TP, et al. Long-term outcomes of imatinib treatment for chronic myeloid leukemia. N Engl J Med. 2017;376(10):917-27. https://doi.org/10.1056/NEJMoa1609324.

116. Mahon FX, Rea D, Guilhot J, Guilhot F, Huguet F, Nicolini F, et al. Discontinuation of imatinib in patients with chronic myeloid leukaemia who have maintained complete molecular remission for at least 2 years: the prospective, multicentre stop imatinib (STIM) trial. Lancet Oncol. 2010;11(11): 1029-35. https://doi.org/10.1016/s1470-2045(10)70233-3.

117. Campiotti L, Suter MB, Guasti L, Piazza R, Gambacorti-Passerini C, Grandi AM, et al. Imatinib discontinuation in chronic myeloid leukaemia patients with undetectable BCR-ABL transcript level: A systematic review and a metaanalysis. Eur J Cancer. 2017;77:48-56. https://doi.org/10.1016/j.ejca.2017.02.028.

118. Saussele S, Richter J, Guilhot J, Gruber FX, Hjorth-Hansen H, Almeida A, et al. Discontinuation of tyrosine kinase inhibitor therapy in chronic myeloid leukaemia (EURO-SKI): a prespecified interim analysis of a prospective, multicentre, non-randomised, trial. Lancet Oncol. 2018;19(6):747-57. https:// doi.org/10.1016/S1470-2045(18)30192-X.

119. Soverini S, Mancini M, Bavaro L, Cavo M, Martinelli G. Chronic myeloid leukemia: the paradigm of targeting oncogenic tyrosine kinase signaling and counteracting resistance for successful cancer therapy. Mol Cancer. 2018;17(1):49. https://doi.org/10.1186/s12943-018-0780-6.

120. Koptyra M, Falinski R, Nowicki MO, Stoklosa T, Majsterek I, NieborowskaSkorska $\mathrm{M}$, et al. BCR/ABL kinase induces self-mutagenesis via reactive oxygen species to encode imatinib resistance. Blood. 2006;108(1):319-27. https://doi.org/10.1182/blood-2005-07-2815.

121. Sokal JE, Baccarani M, Tura S, Fiacchini M, Cervantes F, Rozman C, et al. Prognostic discrimination among younger patients with chronic granulocytic leukemia: Relevance to bone marrow transplantation. Blood. 1985;66(6):1352-7. https://doi.org/10.1182/blood.v66.6.1352.1352.

122. Pfirrmann M, Clark RE, Prejzner W, Lauseker M, Baccarani M, Saussele S, et al. The EUTOS long-term survival (ELTS) score is superior to the Sokal score for predicting survival in chronic myeloid leukemia. Leukemia. 2020;34(8):213849. https://doi.org/10.1038/s41375-020-0931-9.

123. Karasuyama H, Miyake K, Yoshikawa S, Yamanishi Y. Multifaceted roles of basophils in health and disease. J Allergy Clin Immunol. 2018;142(2):370-80. https://doi.org/10.1016/j.jaci.2017.10.042.

124. Görgens A, Radtke S, Möllmann M, Cross M, Dürig J, Horn PA, et al. Revision of the human hematopoietic tree: granulocyte subtypes derive from distinct hematopoietic lineages. Cell Reports. 2013;3(5):1539-52. https://doi.org/10.1 016/j.celrep.2013.04.025.

125. Qi X, Hong J, Chaves L, Zhuang Y, Chen Y, Wang D, et al. Antagonistic regulation by the transcription factors C/EBPa and MITF specifies basophil and mast cell fates. Immunity. 2013;39(1):97-110. https://doi.org/10.1016/j. immuni.2013.06.012.

126. Siracusa MC, Saenz SA, Hill DA, Kim BS, Headley MB, Doering TA, et al. TSLP promotes interleukin-3-independent basophil haematopoiesis and type 2 inflammation. Nature. 2011;477(7363):229-33. https://doi.org/10.1038/na ture10329.

127. Valent $\mathrm{P}$, Horny HP, Arock M. The underestimated role of basophils in $\mathrm{Ph}^{+}$ chronic myeloid leukaemia. Eur J Clin Invest. 2018;48(10). https://doi.org/1 0.1111/eci.13000.

128. Kobayashi S, Kimura F, Ikeda T, Osawa Y, Torikai H, Kobayashi A, et al. BCRABL promotes neutrophil differentiation in the chronic phase of chronic myeloid leukemia by downregulating c-Jun expression. Leukemia. 2009; 23(9):1622-7. https://doi.org/10.1038/leu.2009.74.

129. Denburg JA, Browman G. Prognostic implications of basophil differentiation in chronic myeloid leukemia. Am J Hematol. 1988;27(2):110-4. https://doi. org/10.1002/ajh.2830270208.

130. Hasford J, Pfirrmann M, Hehlmann R, Allan NC, Baccarani M, Kluin-Nelemans $J C$, et al. A new prognostic score for survival of patients with chronic myeloid leukemia treated with interferon alfa. J Natl Cancer Inst. 1998; 90(11):850-8. https://doi.org/10.1093/jnci/90.11.850.

131. Hasford J, Baccarani M, Hoffmann V, Guilhot J, Saussele S, Rosti G, et al. Predicting complete cytogenetic response and subsequent progression-free survival in 2060 patients with CML on imatinib treatment: The EUTOS score. Blood. 2011;1 18(3):686-92. https://doi.org/10.1182/blood-2010-12-319038.

132. Lundberg $L G$, Lerner $R$, Sundelin $P$, Rogers R, Folkman J, Palmblad J. Bone marrow in polycythemia vera, chronic myelocytic leukemia, and myelofibrosis has an increased vascularity. Am J Pathol. 2000;157(1):15-9. https://doi.org/10.1016/S0002-9440(10)64511-7.

133. Zhelyazkova AG, Tonchev AB, Kolova P, Ivanova L, Gercheva L. Prognostic significance of hepatocyte growth factor and microvessel bone marrow density in patients with chronic myeloid leukaemia. Scand J Clin Lab Invest. 2008;68(6):492-500. https://doi.org/10.1080/00365510701854991.

134. Kim JG, Sohn SK, Kim DH, Baek JH, Lee NY, Suh JS, et al. Clinical implications of angiogenic factors in patients with acute or chronic leukemia: 
Hepatocyte growth factor levels have prognostic impact, especially in patients with acute myeloid leukemia. Leuk Lymphoma. 2005;46(6):885-91. https://doi.org/10.1080/10428190500054491.

135. De Paulis A, Prevete N, Fiorentino I, Rossi FW, Staibano S, Montuori N, et al. Expression and functions of the vascular endothelial growth factors and their receptors in human basophils. J Immunol. 2006;177(10):7322-31. https://doi.org/10.4049/jimmunol.177.10.7322.

136. Mayerhofer M, Valent $P$, Sperr WR, Griffin JD, Sillaber C. BCR/ABL induces expression of vascular endothelial growth factor and its transcriptional activator, hypoxia inducible factor-1a, through a pathway involving phosphoinositide 3-kinase and the mammalian target of rapamycin. Blood. 2002;100(10):3767-75. https://doi.org/10.1182/blood-2002-01-0109.

137. Cerny-Reiterer S, Ghanim V, Hoermann G, Aichberger KJ, Herrmann H, Muellauer $L$, et al. Identification of basophils as a major source of hepatocyte growth factor in chronic myeloid leukemia: A novel mechanism of BCR-ABL1-independent disease progression. Neoplasia. 2012;14(7):572-84. https://doi.org/10.1593/neo.12724.

138. Samorapoompichit $P$, Kiener HP, Schernthaner GH, Jordan JH, Agis $H$, Wimazal F, et al. Detection of tryptase in cytoplasmic granules of basophils in patients with chronic myeloid leukemia and other myeloid neoplasms. Blood. 2001;98(8):2580-3. https://doi.org/10.1182/blood.V98.8.2580.

139. Blair RJ, Meng H, Marchese MJ, Ren S, Schwartz LB, Tonnesen MG, et al. Human mast cells stimulate vascular tube formation. Tryptase is a novel, potent angiogenic factor. J Clin Invest. 1997;99(11):2691-700. https://doi. org/10.1172/JCl119458.

140. Ruoss SJ, Hartmann T, Caughey GH. Mast cell tryptase is a mitogen for cultured fibroblasts. J Clin Invest. 1991;88(2):493-9. https://doi.org/10.1172/ JCl115330.

141. Buesche G, Georgii A, Duensing A, Schmeil A, Schlue J, Kreipe HH. Evaluating the volume ratio of bone marrow affected by fibrosis: A parameter crucial for the prognostic significance of marrow fibrosis in chronic myeloid leukemia. Hum Pathol. 2003;34(4):391-401. https://doi.org/1 0.1053/hupa.2003.58.

142. Buesche G, Ganser A, Schlegelberger B, von Neuhoff N, Gadzicki D, Hecker $\mathrm{H}$, et al. Marrow fibrosis and its relevance during imatinib treatment of chronic myeloid leukemia. Leukemia. 2007;21(12):2420-7. https://doi.org/1 0.1038/sj.leu.2404917.

143. Verfaillie CM, McCarthy JB, McGlave PB. Mechanisms underlying abnormal trafficking of malignant progenitors in chronic myelogenous leukemia: Decreased adhesion to stroma and fibronectin but increased adhesion to the basement membrane components laminin and collagen type IV. J Clin Invest. 1992;90(4):1232-41. https://doi.org/10.1172/JCl115985.

144. Zhang B, Ho YW, Huang Q, Maeda T, Lin A, Lee SU, et al. Altered microenvironmental regulation of leukemic and normal stem cells in chronic myelogenous leukemia. Cancer Cell. 2012;21(4):577-92. https://doi org/10.1016/j.ccr.2012.02.018.

145. Lambeir AM, Proost P, Durinx C, Bal G, Senten K, Augustyns K, et al. Kinetic investigation of chemokine truncation by CD26/dipeptidyl peptidase IV reveals a striking selectivity within the chemokine family. J Biol Chem. 2001; 276(32):29839-45. https://doi.org/10.1074/jbc.M103106200.

146. Aichberger K, Mayerhofer M, Vales A, Krauth MT, Gleixner KV, Bilban M, et al. The CML-related oncoprotein BCR/ABL induces expression of histidine decarboxylase (HDC) and the synthesis of histamine in leukemic cells. Blood. 2006;108(10):3538-47. https://doi.org/10.1182/blood-2005-12-028456.

147. Ratajczak MZ, Marlicz W, Ratajczak J, Wasik M, Machalinski B, Carter A, et al. Effect of hepatocyte growth factor on early human haemopoietic cell development. Br J Haematol. 1997;99(1):228-36. https://doi.org/10.1046/j.13 65-2141.1997.3563170.x.

148. Graham GJ, Wright EG, Hewick R, Wolpe SD, Wilkie NM, Donaldson D, et al. Identification and characterization of an inhibitor of haemopoietic stem cell proliferation. Nature. 1990;344(6265):442-4. https://doi.org/10.1038/344442a 0 .

149. Broxmeyer HE, Sherry B, Cooper S, Lu L, Maze R, Beckmann MP, et al. Comparative analysis of the human macrophage inflammatory protein family of cytokines (chemokines) on proliferation of human myeloid progenitor cells. Interacting effects involving suppression, synergistic suppression, and blocking of suppression. J Immunol. 1993;150(8 Pt 1): 3448-58.

150. Bachelerie F, Ben-Baruch A, Burkhardt AM, Combadiere C, Farber JM, Graham GJ, et al. International Union of Basic and Clinical Pharmacology. [corrected]. LXXXIX. Update on the extended family of chemokine receptors and introducing a new nomenclature for atypical chemokine receptors. Pharmacol Rev. 2014;66(1):1-79. https://doi.org/10.1124/pr.113.007724.

151. Wark G, Heyworth CM, Spooncer E, Czaplewski L, Francis JM, Dexter TM, et al. Abl protein kinase abrogates the response of multipotent haemopoietic cells to the growth inhibitor macrophage inflammatory protein-1 alpha. Oncogene. 1998;16(10):1319-24. https://doi.org/10.1038/sj. onc.1201914.

152. Baba T, Naka K, Morishita S, Komatsu N, Hirao A, Mukaida N. MIP-1a/CCL3mediated maintenance of leukemia-initiating cells in the initiation process of chronic myeloid leukemia. J Exp Med. 2013;210(12):2661-73. https://doi. org/10.1084/jem.20130112

153. Baba T, Tanabe Y, Yoshikawa S, Yamanishi Y, Morishita S, Komatsu N, et al. MIP-1a/CCL3-expressing basophil-lineage cells drive the leukemic hematopoiesis of chronic myeloid leukemia in mice. Blood. 2016;127(21): 2607-17. https://doi.org/10.1182/blood-2015-10-673087.

154. Mansfield R, Able S, Griffin P, Irvine B, James I, Macartney M, et al. Chapter 2 CCR5 Pharmacology Methodologies and Associated Applications. Methods Enzymol. 2009:17-55.

155. Jain S, Harris J, Ware J. Platelets: Linking hemostasis and cancer. Arterioscler Thromb Vasc Biol. 2010;30(12):2362-7. https://doi.org/10.1161/ATVBAHA.11 0.207514 .

156. Repsold L, Pool R, Karodia M, Tintinger G, Joubert AM. An overview of the role of platelets in angiogenesis, apoptosis and autophagy in chronic myeloid leukaemia. Cancer Cell Int. 2017;17(1). https://doi.org/10.1186/s1293 5-017-0460-4

157. Rabellino EM, Levene RB, Nachman RL, Leung LLK. Human megakaryocytes. III. Characterization in myeloproliferative disorders. Blood. 1984;63(3):615-22. https://doi.org/10.1182/blood.v63.3.615.615

158. Jacobsson S, Carneskog J, Ridell B, Wadenvik H, Swolin B, Kutti J. Flow cytometric analysis of megakaryocyte ploidy in chronic myeloproliferative disorders and reactive thrombocytosis. Eur J Haematol. 1996;56(5):287-92. https://doi.org/10.1111/j.1600-0609.1996.tb00717.x.

159. Jacobsson S, Wadenvik H, Kutti J, Swolin B. Low megakaryocyte ploidy in Ph-positive chronic myelogenous leukemia measured by flow cytometry. Am J Clin Pathol. 1999;111(2):185-90. https://doi.org/10.1093/ajcp/111.2.185.

160. Thiele J, Schmitz B, Gross H, Kvasnicka HM, Niederle N, Leder LD, et al. Fluorescence in-situ hybridization (FISH) reveals that in chronic myelogenous leukaemia (CML) following interferon-a therapy, normalization of megakaryocyte size is associated with the loss of bcr/abl translocation. Histopathology. 1997;31(3):215-21. https://doi.org/10.1046/j.1365-2559.1 997.2480853.x.

161. Thiele J, Kvasnicka HM, Varus E, Ollig E, Schmitt-Graeff A, Staib P, et al. Megakaryocyte features and bcr/abl translocation in chronic myeloid leukemia following imatinib mesylate (STI571) therapy - A fluorescence insitu hybridization study. Leuk Lymphoma. 2004;45(8):1627-31. https://doi. org/10.1080/10428190410001683732.

162. Hussein K, Stucki-Koch A, Göhring G, Kreipe H, Suttorp M. Increased megakaryocytic proliferation, pro-platelet deposition and expression of fibrosisassociated factors in children with chronic myeloid leukaemia with bone marrow fibrosis. Leukemia. 2017;31(7):1540-6. https://doi.org/10.1038/leu.2017.73.

163. Buesche G, Hehlmann $R$, Hecker $H$, Heimpel $H$, Heinze B, Schmeil A, et al. Marrow fibrosis, indicator of therapy failure in chronic myeloid leukemia Prospective long-term results from a randomized-controlled trial. Leukemia. 2003;17(12):2444-53. https://doi.org/10.1038/sj.leu.2403172.

164. Tanabe Y, Kawamoto S, Takaku T, Morishita S, Hirao A, Komatsu N, et al. Expansion of senescent megakaryocyte-lineage cells maintains CML cell leukemogenesis. Blood Adv. 2020;4(24):6175-88. https://doi.org/10.1182/ bloodadvances. 2020003117.

165. Nolte M, Werner M, Ewig M, Von Wasielewski R, Link H, Diedrich $H$, et al. Megakaryocytes carry the fused bcr-abl gene in chronic myeloid leukaemia: A fluorescence in situ hybridization analysis from bone marrow biopsies. Virchows Arch. 1996:427(6):561-5. https://doi.org/10.1007/bf00202886.

166. Hernandez-Segura A, Nehme J, Demaria M. Hallmarks of Cellular Senescence. Trends Cell Biol. 2018;28(6):436-53. https://doi.org/10.1016/j. tcb.2018.02.001.

167. Takeuchi S, Takahashi A, Motoi N, Yoshimoto S, Tajima T, Yamakoshi K, et al. Intrinsic cooperation between p16INK4a and p21Waf1/Cip1 in the onset of cellular senescence and tumor suppression in vivo. Cancer Res. 2010;70(22): 9381-90. https://doi.org/10.1158/0008-5472.can-10-0801.

168. Besancenot $R$, Chaligné $R$, Tonetti $C$, Pasquier $F$, Marty $C$, Lécluse $Y$, et al. A senescence-like cell-cycle arrest occurs during megakaryocytic maturation: 
Implications for physiological and pathological megakaryocytic proliferation. PLoS Biol. 2010;8(9). https://doi.org/10.1371/journal.pbio.1000476.

169. Faget DV, Ren Q, Stewart SA. Unmasking senescence: context-dependent effects of SASP in cancer. Nat Rev Cancer. 2019;19(8):439-53. https://doi. org/10.1038/s41568-019-0156-2.

170. Naka K, Hirao A. Regulation of hematopoiesis and hematological disease by TGF- $\beta$ family signaling molecules. Cold Spring Harb Perspect Biol. 2017. https://doi.org/10.1101/cshperspect.a027987.

171. Bastola S, Pavlyukov MS, Yamashita D, Ghosh S, Cho H, Kagaya N, et al. Glioma-initiating cells at tumor edge gain signals from tumor core cells to promote their malignancy. Nat Commun. 2020;11(1):4660. https://doi.org/1 0.1038/s41467-020-18189-y.

\section{Publisher's Note}

Springer Nature remains neutral with regard to jurisdictional claims in published maps and institutional affiliations. 